Mezhep Araşttrmaları Dergisi 14, sy. 1 (Bahar 2021): 410-444

\title{
PROF. DR. HASAN ONAT'IN DİN ÖĞRETİMİ PROGRAM ÇALIŞMALARINA VE DERS KITTAPLARININ YAZIMINA KATKILARI
}

\author{
Hasan Onat's Contributions to Religious Education Program \\ Studies and Writing Textbooks
}

\section{Osman AYDINLI*}

\section{öz}

Türkiye'de Din öğretimi ve Yüksek Din Öğretimi alanlarında farklı dönemlerde program çalışmaları yapıldığı bilinmektedir. Bu alana yönelik program çalıșmalarında Ankara Üniversitesi İlahiyat Fakültesi'nin ve akademik kadrosunun aktif bir rol üstlendiği dikkat çekmektedir. Hasan Onat'in da, eğitim-öğretimin farklı alanlarında deneyimleri, projeleri, faaliyetleri ve akademik çalışmaları oldu. O, din ve değerler alanında ortaya çıkan bilgi boşluğunun insanlığın geleceği aç1sından ciddi bir tehdit olușturacağını savundu. Özellikle İlahiyat alanında yürütülen eğitim ve öğretime ilişkin özgün fikirleri vard1. Türkiye'nin de içinde olduğu İslâm dünyasının somut bir ilahiyat eğitimi meselesinin olduğunu hem yazılarında hem de ilmi platformlarda sürekli gündeme getirdi. Ayrıca eğitimin farklı düzeylerinde program geliştirme komisyonlarında yer alarak ve ders kitaplar yazarak katk1 sağlad1. 1997'yi takip eden y1llarda, orta öğretimde ve yüksek öğretimde okutulan derslere yönelik müfredat programlarının yeniden yapılandırılmas1 faaliyetlerinde görev yapt1. Türkiye'de din öğretimine ilişkin yazdığı ders kitaplarında; İslâm'da düşünce özgürlüğü, insanın değeri, değişimin gerekliliği ve yenilenme konularına yoğunlaştı.

\section{Abstract}

It is known that program works are carried out in different periods in the area of Religious Education and Higher Religious Education in Turkey. It is noteworthy that Ankara University Faculty of Theology and its academic staff take an active role in the program studies in this field. As an academic, Hasan Onat also had experiences, projects, activities and academic studies in different fields of education. He argued that the knowledge cavity emerging in the field of religion and values would pose a serious threat of the future of humanity. He had original ideas about education and teaching, especially in the field of Theology. He brought up that Turkey and the Islamic world is a concrete theological education matters in his writings and on scientific platforms. He also contributed by taking part in program improvement commissions at different levels of education and by writing textbooks. In the years following 1997, he took part in the renewal activities of Imam-Hatip High Schools and Primary Education Religious Culture and Morals curriculum. In the books he wrote on religious education in Turkey; He focused on freedom of thought, the value of human, the necessity of change and renewal in Islam.

* Prof. Dr., Ankara Üniversitesi İlahiyat Fakültesi, Temel İslam Bilimleri, İslam Mezhepleri Tarihi, Ankara, Türkiye/ osmanaydinli@gmail.com/ orcid.org/0000-0003-4716-0522.

\begin{tabular}{ccc} 
Başvuru|Submission & Kabul|Accept & Yayın |Publish \\
01.05 .2021 & 21.06 .2021 & 30.06 .2021 \\
\hline
\end{tabular}

DOI: $\quad 10.18403 /$ emakalat.930912 
Anahtar Kelimeler: İslâm Ortak Paydas1, Mezhep, Din Öğretimi, Ilahiyat Fakültesi, İmam-Hatip Liseleri.
Key Words: Islam Common Denominator, Sects, Religious Education, Divinity Faculty, Imam-Hatip High Schools.

\section{GİRIS}

Prof. Dr. Hasan Onat hem günümüzdeki Müslüman düşüncesine hem de İslâm Mezhepleri Tarihi disiplinine yöntem ve muhteva açısından değerli katkılar sağlayan seçkin hocalardan biri olarak tanınd1. O, mezheplerin ve dinî grupların zihniyet dünyasını tahlil ederken güncel konularla da ilişkilendiren, hedef kitlesi olan öğrencilerine ve fikrî takipçilerine karşılaştırma imkânı sunan çok yönlü bir bilim adamıdı. İslâm bilimlerinin yeniden inşasına önem veren Onat'in düşünce dünyasında Kur'ân'in merkezî bir rolü vardı. Vahyî bilgi konseptinden hareketle Kur'ân'in Allah'in ayeti olmasına benzer şekilde aklın ve tabiatın da Allah'ın ayeti olduğunu dile getirdi. Bu sebeple ak1, bilim ve vahyin daima birbirlerinin tamamlayıc1lar ${ }^{1}$ olduğunu vurguladı. Onun düşünce evreninin oluşmasında akıl, düşünce ve özgür irade ile donatılan bireyin üstlendiği görev anlayış1 doğrultusunda kutsal kitabı anlamanın ve bu yönde hayatı anlamlandırmanın etkisi oldukça açıktır. Onat'a göre inanç alanında olduğu gibi ibadetler ve ahlâk alanında da belirleyici olan Kur'ân-1 Kerim'dir. Vahiy tarafindan belirlenmiş olan bu ilkeler, Hz. Muhammed'in örnekliği ile onun sağlığında belirgin bir şekilde ortaya konmuştur. Bunun ötesinde yeni bir inanç esası ve yeni bir ibadet söz konusu değildir. Bu yüzden "İslâm ortak paydası" olarak kavramsallaştırdığı ve tasnif ettiği kurucu ilkelere bağl1 kalmaya özen gösterdi. $\mathrm{Bu}$ yöndeki söylemi, dini gelenekle ve dini bilgi havuzuyla ilgilenenlerin dikkatini çekti; "Hz. Peygamber döneminde kuşatıcı kimlik Müslümanlıktır; yani Müslüman insan vardır. İslâm ortak paydasının bilgi boyutunda belirleyici olan tek bilgi kaynağı vahiydir.“2

1 Hasan Onat, "İslam Bilimleri ve Yöntemi Açısından Tarihin Anlam ve Önemi", Kur'an ve İslami Ilimlerin Anlaşılmasında Tarihin Önemi, ed. M. Mahfuz Söylemez (Ankara: Ankara Okulu Yayınları, 2013), 29-30.

2 İslâm ortak paydasına ilişkin daha geniş bilgi için bk. Hasan Onat, İslam Ortak Paydası ve Mezhep Gerçeği (İstanbul: Endülüs Yayınları, 2019), 23-199; Hasan Onat-Sönmez Kutlu, İslam Mezhepleri Tarihi El Kitabı (Ankara: Grafiker Yayınları, 2012), 37-38. 
Onat'a göre aynı zamanda aklın da ilkeleri olan Kur'ân-1 Kerim'in temel kurucu ilkelerinin, devrim niteliği taşıdığını gözden ırak tutmamak gereklidir. Bu ilkeler, bireyin anlam dünyasını ve tarihi yeniden inşa sürecini başlatmış, bunun yanı sıra insanın evrende özne olduğu gerçeğini de öne çıkarmıştır. ${ }^{3}$ Eleştirel inşacı bir yaklaşım sergileyen Onat'a göre genç jenerasyonun zihin dünyasını yeniden inşa etmenin gereği oldukça açıktır. Kitaba ve bilime dayalı medeniyetin omurgasını, bilginin vazgeçilemez bir değer olduğunun farkında olan Müslüman bireylerin ortaya koyduğu bilgi birikimi oluşturacaktır.

Hasan Onat'ın, eğitimin farklı alanlarında ve özellikle de İlahiyat alanındaki eğitim ve öğretime ilişkin özgün fikirleri vardı ve program geliştirme komisyonlarında yer alarak ve ders kitapları yazarak bunu gerçekleştirebilme imkânına sahip oldu. Bu çabalara ve çalışmalara geçmeden önce Hasan Onat'ın bilim anlayışına ve din eğitimine yönelik düşüncelerine değinmek istiyoruz.

Onat, insanlığın geleceği açısından insanın fitratına uygun yeni bir uygarlığın mayalanabilmesi için yeni bir din ve bilim anlayışının gerekliliğini savunur. Bu bağlamda kök bilim paradigması formülasyonu üzerinde özenle durmuştur. Bu çerçevede belirlenen yöntem ilkeleri, hem doğa bilimlerine, hem de beşeri bilimlere yön gösterecek niteliktedir. Tüm bilim dalları bu ortak zeminde kendi yöntemlerini kurma ve uygulama imkânına sahip olabilirler. ${ }^{4}$

Onat, İlâhiyat bilimlerinin, bilimler yelpazesindeki yerini de belirlemeye gayret eder. Bu bilimler, insan bilimleri alanında yer alırlar ve onun bir alt şubesi olarak araştırmalarını yürütürler. En az tabiat bilimleri kadar bilimsel bir niteliğe sahiptirler. Dinin doğru bir şekilde anlaş1ması gerektiğine göre din olgusu ve her din, bilimin konusu olmak durumundadır. İlahiyat fakültelerinde Tefsir, F1kıh, Hadis, İslâm Tarihi, Kelâm, Tasavvuf, İslâm Mezhepleri Tarihi gibi bilim dallarında ilmi usûller ve teknikler kullanılarak bilgiye ulaşılır, eleştirel zihniyet çerçevesinde İslâm geleneğinden gelen birikimden ne şekilde yararlanılacağı tartışılır ve böylece doğru bir din anlayışının ortaya

${ }^{3}$ Hasan Onat, "Bilim, Bilimsel Yöntem ve İslâm/İlâhiyat Bilimlerinde (Ulûmu Dîniyye) Yöntem Sorunu", Modern Dönemde Dinî İimlerin Temel Meseleleri İlmî Toplantı (İstanbul: İSAM Yayınları, 2007), 41-45.

4 Onat, "Tarihin Anlam ve Önemi”, 25-26. 
çıkması hedeflenir. Dinin bilimin konusu olması, din alanındaki bilginin bilimsel bilgiye dönüşmesi anlamina gelmektedir, yoksa onun egemenliğinde olduğu anlamına gelmez. ${ }^{5}$

Onat, bilim anlayışını temellendirmede Kur'ân-1 Kerim öğretisine yönelir. Kur'ân'ın ilmi teşvik etmesi, Müslüman kimliği eşyanın hakikatini, olay ve olguların mahiyetini/iç yüzünü anlamaya yöneltmiştir. Bununla da kalmamış insanı bir "yitik" ararcasına bilginin peşine takmıştır. Bu sebeple tarihsel süreçte Müslüman birey, ulaşılabilen her türlü bilgiyi öğrenmekle kalmamış aynı zamanda yeni bilgi alanları keşfetmiş ve bilimsel bilgi üretmiştir. Sağlam ve güvenilebilir bilgi üretme süreçlerinin, mâlûmatla bilimsel bilgi arasındaki farkı belirginleştirmiş ve dinî bilimlerin birçok alanında alimler yetişmiştir. Onat'a göre Kur'ân'ın bilgi ve bilim konusunda oluşturduğu bilinç düzeyi, Hz. Muhammed'in okuma-yazmayı teşvik etmesi, ilim yapmanın farz olarak görülmesi ve bilgili insanların övgüye değer görülmesiyle sosyal yapıda karşılık bulmuştur. $O$, bilgiye verilen değer bağlaminda Hz. Peygamber'in vahyi yazdırmas1, insanlara ilahi mesaj1 aktarması, Bedir Savaşı'nın ardından müşrik esirlerden okuma yazma bilenlerin Müslümanlara bunu öğretmeleri karş1lığında özgürlüklerine kavuşmaları gibi uygulamaları dile getirir. Bunlar, bilginin kayıt altına alınması konusunda önemli adımlardır. Hatta Onat, bu noktada iddiasını biraz daha ileri taşıyarak bu tür uygulamaları belki de yazının icadından sonraki en büyük adımlar olarak niteler. Böylece Müslümanlar tarafından insanlığın kaderini kökten değiştirecek yeni bir bilim anlayışının ve gün geçtikçe büyüyen ilmi geleneğin ve birikimin temelleri atılmıştır. ${ }^{6}$

Onat'a göre Müslümanların mevcut bilim ve tarih algısı, Temel İslâm Bilimleri olarak adlandırılan alanlardaki birikiminden yararlanarak yeni bir bilgi üretecek nitelikte değildir. $\mathrm{O}$, bu konudaki en belirgin eksikliğin sorunlu tarih bilgi-bilinci ve yöntem yoksunluğu olduğunu düşünür. Geçmişi idealize eden ve kutsallaştıranların zihninde "gelişme" fikrinin olmayacağını söyleyen Onat, bu tür insanların maziye ve mâlûmata mahkum olmak zorunda kalacaklarını söy-

\footnotetext{
5 Onat, "İlâhiyat Bilimlerinde (Ulûmu Dîniyye) Yöntem Sorunu", 49

6 Onat, "Tarihin Anlam ve Önemi", 30 vd.
} 
ler. Yöntem bilincine erişilmeden bilimden ve bilimsellikten söz edilemez. Temel İslâm Bilimleri'nin her birinde üretilen bilgi ve fikir, insan tarafından üretilmesi ve sunulması nedeniyle beşeri bilgi kapsamında ele alınmalıdır. ${ }^{7}$ Bu da bilginin doğrulanabilir ve yanlışlanabilir olabileceği ve olguya eleştirel yaklaşılması gerektiği anlamına gelir.

Eğitimin farklı süreçlerinde din eğitiminin gerekliliği ve nasıl yapılması gerektiği konusu çözülmeyi bekleyen bir problem olarak gündemdeki canlılığını sürdürmektedir. Dinin insanlığın vazgeçemeyeceği ve dişlayamayacağ bir olgu olduğundan söz eden Hasan Onat, din ve değerler alanında ortaya çıkan bilgi boşluğunun insanlığın geleceği açısından ciddi bir tehdit teşkil edeceğini düşünür. Bu boşluğu gidermenin dindar aydın yetiştirmek ve köklü eğitim politikaları tasarlamakla mümkün olduğuna işaret eder. Eğitimin üniversal nitelik taşıyan amaçlarının gerçekleşebilmesi için, dinin desteğine ihtiyaç bulunmaktadır. Eğitimin "insanın kendini tanıması ve anlaması, doğru düşünmesi, bilinçli davranışlar geliştirmesi, insanın potansiyel yeteneklerinin en iyi şekilde geliştirilmesi ve etkin k1lınması, üretkenliğin artırılması, insanın sosyalleşmesi, geçmişin birikiminin en iyi şekilde yeni nesillere aktarılması" olarak tanımlanan temel amaçlarına ulaşılmasında sağlıklı din anlayışından yararlanılmasını önerir. Eğitimin amaçladığı zihinsel değişimi, ancak sağlıklı bir din anlayışı gerçekleştirebilir. ${ }^{8}$

İnsanın niçin din eğitimine ihtiyacı olduğu konusunu sorgulayan Onat'a göre, insanın kendini gerçekleştirmesinin en geçerli yolu Allah'ın rizasina ve sevgisine talip olmaktır. Aynı zamanda sosyal bir varlık olan insanın, toplumu görmezlikten gelerek kendini inşa edemeyeceği açıktır. Bu açıdan bakıldığında din, bireyin doğru düşünmesinde, farkındalık oluşturmasında ve en iyiyi gerçekleştirmesinde önemli ölçüde katkı sağlayan bir araç olarak karşımıza çıkmaktadır. Bu konuda eğitim-öğretimin tek başına bir motivasyon kaynağı olduğu söylenemez. İnsanlık tarihi boyunca gönderilen peygamberlerin

7 Daha geniş bilgi için bk. Onat, "Tarihin Anlam ve Önemi", 33-67; Osman Aydınl1, "Hasan Onat (1957-)", Tanzimattan Günümüze Dinî ve Tasavvufî Düşünce Temsilcileri, ed. Süleyman Hayri Bolay (Ankara: Nobel Yayınları, 2015), 6:42344246.

8 Hasan Onat, Türkiye'de Din Anlayışında Değişim Süreci (İstanbul: Endülüs Yayınları, 2016), $133 \mathrm{vd}$. 
esas görevleri, Allah katından aldıkları vahiyle insanları uyarmak ve doğru düşünmenin yollarını göstermek olmuştur. Eğitim, bireyin yaratıcı kabiliyetlerinin keşfedilmesini, geliştirilmesini ve etkin kılınmasını sağlamaktadır. Din, insandan yaratıcı yeteneklerin kullanılmasını, insanlık değerlerine ulaşmasına imkân sağlayacak kültürün ve uygarlığın yaratılmasını talep eder. Eğitim, bu sürecin en kazançlı ve en verimli şekilde nasıl başarılabileceğini insanlara öğretir. ${ }^{9}$

Onat, insanın evrenin merkezinde oluşunu göz ardı etmez. Din, bilim ve eğitim; insanın kendini anlamasına yardımcı olur. Din, bünyesinde taşıdığ temel iletişim kodları sayesinde, insanların birbirlerini anlamalarını kolaylaştırır. Eğitim, tek taraflı değil, iki taraflı etkin bir süreç olduğuna göre, dini bilen insanların birbirlerini anlamaları daha kolay olacaktır. Bu da eğitim faaliyetlerinin kaliteli olmasını sağlar ve hedeflere daha kolay ulaşmayı temin eder. Din, bireye temel hak ve özgürlüklerini sahiplenmesini öğütler ve bunun insan olmanın gereği olduğunu belirtir. Din, insanı kendine ve topluma yabanc1lassmaktan korur. Eğitim de, temelde bireyin özgür olmasını ve özgürlüğün anlamını keşfetmesini sağlar. Dinin temelinde nasıl insan sevgisi varsa eğitim de insanın özünde mevcut olan bu sevginin ortaya çıkarılmasında etkin olur. Onat, bu noktada din alanındaki bilimsel bilginin niteliğine de değinir. Ona göre dine ilişkin nitelikli sağlam bilgi ve doğru bir din anlayışı eğitimle gerçekleşebilir. ${ }^{10}$

Hasan Onat, din eğitimi ve öğretiminin devlet kontrolünde verilmesinin gerekliliğini, Tevhid-i Tedrisat kanununu dayanak alarak ortaya koymaya çalışır. Türkiye'nin özel koşulları ve İslâm dininin bazı yapısal özellikleri, din öğretiminin devletin denetimi ve gözetimi altında, devletin resmi kurumlarında yapılmasını bir mecburiyet haline getirmiştir. Onat dönemin tartışmalı konuları sekiz yıllık kesintisiz zorunlu temel eğitim, İmam Hatip Liseleri, seçmeli Kur'ân okuma ve meali dersleri gibi konularda da fikirlerini ve buna dayalı önerilerini ${ }^{11}$ de kamuoyu ile paylaşmıştır.

Çalışmamızın bu bölümünden itibaren Hasan Onat'ın İlahiyat müfredatının hazırlanmasına yönelik çalışmaları, Din Kültürü ve

\footnotetext{
9 Onat, Din Anlayışında Değişim Süreci, 137 vd.

10 Onat, Din Anlayışında Değişim Süreci, 139.

11 Onat, Din Anlayışında Değişim Süreci, 141-142.
} 
Ahlâk Bilgisi (DKAB) programlarının yapılandırılması; Lise ve İmamHatip Lisesi gibi orta dereceli okullar ve Yüksek Din Öğretimi'ne yönelik ders kitaplarının yazımına ilişkin katkıları üzerine yoğunlaşmak istiyoruz.

\section{Din öğretimi program çalışmaları}

Türkiye'de Din öğretimi ve Yüksek Din Öğretimi alanlarında farklı dönemlerde komisyonlar oluşturulmuş ve program çalışmaları yapılmıştır. Bu çalışmalarda Ankara Üniversitesi İlahiyat Fakültesi'nin aktif bir rol üstlendiği dikkat çekmektedir. Buna örnek olarak 1982 ve 1997 yıllarında gerçekleştirilen İlahiyatların müfredatının yenilenmesi, 1998 yılındaki İmam Hatip Liseleri'nin yeniden yapilanmas1, 2000-2001 Öğretim y1lındaki 4., 5., 6., 7. ve 8. sınıfları kapsayan İ1köğretim Din Kültürü ve Ahlâk Bilgisi dersi programlarının hazırlanmas1 ${ }^{12}$ gibi çalışmalar gösterilebilir. Bunun yanı sıra Anadolu Üniversitesi Açık Öğretim Fakültesi'nin Yükseköğretim Yürütme Kurulu'nun 11.07.1997 tarih ve 97.23.1660 sayılı kararı ile 11 Aralık 1997'de uygulamaya geçen İlahiyat Ön lisans Program1, Ankara Üniversitesi İlahiyat Fakültesi'nin "uzaktan eğitim koordinasyonu" ve "akademik danışmanlığı" ile yürütülmektedir. ${ }^{13}$

Hasan Onat'in yukarda belirtilen eğitim-öğretime yönelik bazı projelerde ve program çalışmalarında aktif olarak görev aldığ 1 ve bunlara ilişkin görüşlerini kamuoyu ile paylaştığı bilinmektedir. O, İlahiyat müfredat programlarının yeniden oluşturulması çalışmalarına katıld1. 1998'den başlayarak 2003'e kadar süren zaman diliminde Milli Eğitim Bakanlığı (MEB) Din Öğretimi Genel Müdürlüğü biriminin öncülük yaptığ ve organize ettiği, İlköğretim Din Kültürü ve Ahlâk Bilgisi ve İmam-Hatip Liseleri müfredat programının yeniden hazırlanması çalışmalarında görev aldı.

İlk olarak Onat'in Yüksek Din Öğretimi'nin önemli akademik yapılanması olarak eğitim-öğretim faaliyeti yürüten İlahiyat programlarına sağladığı katkı üzerinde duracağız.

12 Milli Eğitim Bakanlığı Tebliğler Dergisi, 63/2517 (Ekim 2000).

13 Onat, Din Anlayışında Değişim Süreci, 114. 


\section{1. İlahiyat programları: Değişimi anlamak ve yenilenme}

Cumhuriyet'in kuruluşuyla birlikte -diğer alanlarda olduğu gibidinî sahada da köklü bir değişim ve dönüşüm kararına imza atılmıştır. Bu çerçevede 3 Mart 1340/1924'de Türkiye Büyük Millet Meclisi'nde çıkarılan bir kanunla Şer'iye Vekâleti kaldırılarak dinî görev ve hizmetleri yürütmek üzere Başvekâlet'e bağl1 "Diyanet İşleri Reisliği” kurumu ihdas edilmiştir. Ayrıca 3 Mart 1340/1924 tarih ve 430 sayılı Tevhid-i Tedrisat Kanunu çıkartılmış ve bütün medrese ve mektepler -bütçeleriyle birlikte- Maârif Vekâleti'ne devredilmiştir. Kanunun amacı eğitim öğretim birliğini sağlamak suretiyle ülkenin insanları arasında düşünce birliğini ve dayanışma ruhunu pekiştirmekti. Bu kanunun yüksek öğretimle ilgili yönünün yenilenmesine yönelik de Dârü'l-Hilâfeti'l-Âliyye Medresesi kapatılmıştır. Bu kurumun yerine Tevhid-i Tedrisat kanununun 4. maddesiyle Dârü'1Fünûn Üniversitesi bünyesinde bir İlahiyat Fakültesi'nin kurulmasına karar verilmiştir. Bu husus, ilgili maddede şu şekilde ifadesini bulmuştur: "Maârif Vekaleti yüksek diniyât mütehassısları yetiştirilmek üzere Dârü'l-Fünun'da bir İlahiyat Fakültesi tesis ve imâmet ve hitabet gibi hidemâtı diniyenin ifası vazifesiyle mükellef memurların yetişmesi için de aynı mektepler küşat edecektir."14

Tevhid-i Tedrisat kanununu yürürlüğe girer girmez 1923-1924 öğretim y1lında 29 tane İmam-Hatip okulu ve İstanbul Dârül-Fünûn İlahiyat Fakültesi açılmıştır. ${ }^{15}$ Türkiye Cumhuriyetinin kuruluşundan günümüze gelinceye dek yüksek din öğretimi alanında sırasıyla Dârü'l-Fünûn İlahiyat Fakültesi, İslâm Tetkikleri Enstitüsü, Ankara Üniversitesi İlahiyat Fakültesi, Yüksek İslâm Enstitüleri, İslâmi İlimler Fakülteleri, Din Bilimleri Fakülteleri, her ilde ve bazı ilçelerde açılan bugün 100'ün üzerine çıkan diğer ilahiyat fakülteleri bulunmaktadır. Bunların her biri için kendi koşullarına, kuruluş amaçlarına ve kadro yapılarına uygun müfredat programları hazırlanmıştır.

14 Tevhid-i Tedrisat Kanunu ve uygulanışı ile ilgili geniş bilgi için bkz. Halis Ayhan, Türkiye'de Din Eğitimi (1920-1998) (İstanbul: M. Ü. İlahiyat Fakültesi Vakf1 Yayınları, 1999), 23-31.

15 Muhammed Şevki Aydın, Cumhuriyet Döneminde Din Eğitimi Öğretmeni Yetiştirme ve İstihdamı (İstanbul: Dem Yayınları, 2005), 56. 
Ülke siyaseti için en önemli kırılma noktalarından biri olan 1980 askeri ihtilali sonrasında yüksek din eğitiminde, zihniyet dönüşümü ve pratik açılardan köklü değişimi sağlayacak bazı düzenlemeler yapılmıştır. Bu süreç, İlahiyat Fakültelerinin müfredat programları aç1sından da önemli bir dönemeç olmuştur. 20 Temmuz 1982 tarihinde alınan ve Yüksek Din Öğretimi'ni dönüştüren ve yeni bir sürece yönelten bir kararla, Yüksek İslâm Enstitüleri, ilahiyat fakültelerine dönüştürülmüştür. Bu doğrultuda İstanbul Yüksek İslâm Enstitüsü, Marmara Üniversitesi'ne, Konya Yüksek İslâm Enstitüsü, Selçuk Üniversitesi‘ne; Kayseri Yüksek İslâm Enstitüsü, Erciyes Üniversitesi'ne; İzmir Yüksek İslâm Enstitüsü, Dokuz Eylül Üniversitesi'ne; Bursa Yüksek İslâm Enstitüsü, Uludağ Üniversitesi'ne ve Samsun Yüksek İslâm Enstitüsü, Ondokuz Mayıs Üniversitesi'ne fakülte statüsünde bağlanmıştır. Ayrıca Erzurum Yüksek İslâm Enstitüsü, İslâmi İlimler Fakültesi'yle birleştirilerek Atatürk Üniversitesi bünyesine alınmıştır. Böylece ilahiyat fakültelerinin sayısı sekize yükselmiştir. Bu dönemde yüksek din öğretiminde daha önce pek de benzerine rastlanmadık bir şekilde Yozgat'taki Yüksek İslâm Enstitüsü, iki öğretim yılı tedrisatın ardından kapatılmıştır. ${ }^{16}$ Sonrasında yeni oluşturulan bu fakültelere ilaveten farklı illerde farklı üniversitelere bağlı ilahiyat fakülteleri açılmıştır.

1982 yılındaki düzenleme esas alınarak İlahiyat programı, 19911992 öğretim yılında yeniden şekillendirilmiştir. 1997 yılı içinde cereyan eden ve etkileri uzun ylllar süren 28 Şubat sürecine gelindiğinde ülkede sayıları 22'ye yükselen İlahiyat fakülteleriyle aktif eğitime devam eden yüksek din öğretimi, alınan bazı kararlar sebebiyle tartışmaların odağı haline gelmiştir. Bu dönem içerisinde 1997 y1lında ilahiyat fakültelerinin hazırlık sınıfları kaldırılmış ve Arapça dersleri dört yıllık program içerisinde dağıtılmıştır. Bir önceki programla karşılaştırıldığında içerik açısından köklü bir değişime gidilmemiş, sürekli ve kısmî bir değişim yaşanmıştır. Ancak alanda öğretmen ihtiyacına yönelik faaliyete başlayan İlköğretim Din Kültürü

16 Yüksek İslam Enstitülerinin Fakülteye dönüştürülme süreci ile ilgili bk. Halis Ayhan, "İlahiyat Fakültesi", Din Eğitimi Araştırmalar Dergisi, 6 (1999): 255268; Mustafa Öcal, "İlahiyat Fakültelerinin Tarihçesi“, Uludağ Üniversitesi İlahiyat Fakültesi Dergisi, $1 / 1$ (1986): 111-123. 
ve Ahlâk Bilgisi Öğretmenliği Bölümü’nde, o dönem yürütülen ilahiyat programına göre temel dinî bilimler alanında daha düşük profilde bir içeriğe sahip olan bir program uygulamaya konulmuştur. Bu sürecin devamında ilahiyat programlarından pedagojik formasyon derslerinin kaldırılması uygulamasına geçilmiştir. 1997-1998 eğitim-öğretim yılındaki düzenlemeyle İlahiyat fakültelerinin programları, İlahiyat Lisans Programı ve İlköğretim Din Kültürü ve Ahlâk Bilgisi Öğretmenliği Programı olmak üzere ikiye ayrılmıștır. Böylece, öğretmen yetiştirme işlevi İlköğretim Din Kültürü ve Ahlâk Bilgisi Öğretmenliği Programı'na devredilmiştir. Bu program, 2006 yılında da Eğitim fakültelerinin uhdesine verilmiştir. ${ }^{17}$ Farklı dönemlerde yürütülen ilköğretim, ortaöğretim ve yüksek öğretimde; din eğitimi ve öğretiminin yeniden yapılandırılması ve yeni programların hazırlanması çalışmalarında Ankara İlahiyat Fakültesi, aktif şekilde rol almış ve önemli bir misyon üstlenmiştir.

Kuruluşundan bugüne İlahiyat fakültelerinde uygulanan programların dayatmacı bir şekilde yapılandırıldığı ve uygulandığına dair görüşler var olagelmiştir. Türkiye'de İlahiyat fakültelerine yönelik eleştiri, tartışma ve değerlendirmelerde genelde meseleye akademik ve bilimsel düzlemde yaklaşımlar yerine, ideolojik ve politik, dahas1 meşrep ve mezhep eksenli yaklaşımlar ağır bastığı için çoğu zaman çözüm arayış süreci sancılı olmuştur. 1997-1998 yılından itibaren yürürlüğe konulan program, yenilenme gereksinimi dikkate alınarak Ankara Üniversitesi İlahiyat Fakültesi öğretim üyeleri tarafından hazırlanmıştır. Ankara Üniversitesi İlahiyat Fakültesi‘nde uygulanmak üzere yine aynı Fakülte bünyesinde komisyonlar marifetiyle hazırlanmış, prosedüre uygun olarak Fakülte Kurulu ve Ankara Üniversitesi Senatosu'ndan geçirilmiş ve YÖK'ün onayına sunulmuştur. Yüksek Öğretim Kurulu da bu öneriyi tüm ilahiyat fakültelerinde \% 30'luk değişiklik hakkı ile uygulanmak üzere yürürlüğe koymuştur. ${ }^{18}$ Hasan Onat da İlahiyat fakültelerinde uygulanan bu program çalışmasını yürüten komisyonda üye olarak görev almış ve aynı zamanda

17 YÖK, İlahiyat Fakülteleri Öğretmen Yetiştirme ve Lisans Programları (Ankara: YÖK Yay., 1998), 43.

${ }_{18}$ Cemal Tosun, "Almanya'da ve Türkiye'de İlahiyat Eğitimi”, Türkiye'de İlahiyat Fakültelerinin Konumu ve Dini Bilginin Niteliği, ed. Mahmut Ay-Rabiye Çetin (Ankara: A.Ü. İlahiyat Fakültesi Yayınları, 2016), 209. 
program Ankara Üniveritesi İlahiyat Fakültesi Akademik Kurulu'nda tartış11ırken komisyonda sözcülük yapmıştır. Bu sebeple 28 Şubat sürecinde yapılandırılan İlahiyat programlarına yönelik üst makamlardan baskı yoluyla dayatıldığı şeklindeki iddialara ve eleştirilere katılmadığını söylemiştir. Ona göre bu söylem, gerçeğe aykırıdır ve programda emeği geçenlere yönelik yapılan bir haksızlıktır. ${ }^{19}$

Onat'a göre bu program bilimsel ve pedagojik anlamda oldukça başarılıdır. Program taslağına ilişkin bu süreçte diğer İlahiyat fakültelerinden de görüş istendiği halde çok az sayıda dönüş olmuş ve program yeniden gözden geçirilerek akademik kurula sunulmuştur. Ankara İlahiyat Fakültesi Akademik Kurulu 03.12.1997 tarihinde bu taslağı gün boyu tartışmıştır. Öneriler doğrultusunda bazı değişikliklere de gidilmiştir. Daha sonra Üniversite Senatosu'nda onaylanarak YÖK'e gönderilmiştir. Yüksek Öğrenim Kurumu (YÖK) tarafından da 2 saatlik Ana Konularıyla Kur’ân dersinin eklenmesi dışında bir değişiklik yapılmamıștır. ${ }^{20}$

Onat, program hazırlama komisyonunun bir üyesi ve sözcüsü olarak süreci en iyi bilen kişilerden biriydi. İlahiyat programlarının uygulanışının üzerinden geçen birkaç yılın ardından tarihe not düşmek anlamında bu süreci bizzat anlatmayı görev saydı. O, komisyonda yer alan öğretim üyeleri olarak birikimleri doğrultusunda daha önce yapılan güzel işleri anlamaya, eksikleri gidermeye, tecrübelerden yararlanmaya ve bilimsel gelişmeleri programa taşımaya özen gösterdiklerini ifade eder. Ama ihtiyaca yönelik bu programa yeni katkılar yap1labileceğini de söylemeden geçmez. Ön koşul olarak da bu programların niteliğiyle ilgili kapsamlı bir tartışma yapmayı gerekli görür. Sadece ders saatleri üzerinden yapılacak bir değişikliğin bilimden ve bilimsel zihniyetten uzak bir yaklaşım olacağını savunur. Programlara yönelik tepkisel tutum ve davranışların hedeflenen amacı sağlamakta yeterli olamayacağını söyler. ${ }^{21} \mathrm{O}$, yeniden gündeme gelen İlahiyat fa-

\footnotetext{
19 Hasan Onat, “İlahiyat Fakültesinde Program Tartışmaları Üzerine”, Türkiye’de İlahiyat Fakültelerinin Konumu ve Dini Bilginin Niteliği, 309.

20 Onat, "İlahiyat Fakültesinde Program Tartışmaları Üzerine", 312.

${ }^{21}$ Onat, "İlahiyat Fakültesinde Program Tartışmaları Üzerine", 309 vd.
} 
kültelerine yönelik program çalışmalarının ideolojik ve politik olabileceğinden kaygı duymaktadır. Bunu da açık bir şekilde söyler ve konuyu tartışmaya açmaktan yana tavır koyar.

Onat bu programa yönelik sorunun esasta öğrenci ve program temelli olmadığ1 görüşündedir. Değiştirilebilir olduğu ifade edilen bu programın etraflıca ve kapsamlı bir şekilde tartışılmadığı görüşündedir. Programa, siyasi veya ideolojik saiklerle müdahale yapılması yanlış olacaktır. Üniversitede olması gereken bilim, bilimsel zihniyet ve bilimsel yöntemin bir gereği olarak herşey etraflıca ortaya konmalı ve tartış1malıdır. ${ }^{22}$ Onat özgürlük bilincinden hareketle Üniversitelerin özgürce bilim üretme sorumluluğundan söz eder. İhtiyaç doğrultusunda bilimin ışığında yeni müfredat programlarının hazırlanabileceğini savunur. Eski programa yönelik temelsiz saldırıdan ziyade eksikliklerin tespit edildiğini ve yerindelik çerçevesinde üniversitelerin kendi kararını kendisinin vermesinden yana olduğunu söyler. ${ }^{23}$

Onat, 1997-1998 öğretim yılından itibaren yürürlüğe giren bu programin, ilk etapta temel ilkelerinin tahlil edilmesi gerektiğini savunmuştur. Esasen İlahiyat Lisans Programı Kur'ân-1 Kerim referanslı bakabilen, geçmişin ilmi mirasını değerlendirebilen, günceli yorumlayabilen ve din eksenli meselelere çözüm sunabilen ilahiyatçllar yetiştirmeyi hedeflemektedir. Dersler sosyal, ekonomik, düşünsel ve kültürel koşulların gerektirdiği temel nitelikleri kazandırmayı amaçlar. ${ }^{24} \mathrm{Bu}$ programda alanın temel bilgilerini kazandıracak derslerin "zorunlu dersler" olarak okutulması tasarlanmıştır. Teori ile pratik arasındaki bütünlüğü temin edecek derslerin ise "seçmeli dersler" olması tercih edilmiştir. Programda mümkün olduğu ölçüde "projeye dayalı dersler" olarak tasarlanan "seçmeli ders" sayısı artırılmıştır. Programın temel ilkeleri ve felsefesi üzerinde açıklamalar

\footnotetext{
22 Onat, "İlahiyat Fakültesinde Program Tartışmaları Üzerine", 310.

23 Onat, "İlahiyat Fakültesinde Program Tartışmaları Üzerine", 311.

${ }_{24}$ M. Sait Yazıcıŏlu, "Cumhuriyetin 75. Y1lında Din Öğretiminde Yeni Hedefler", Ankara Üniversitesi İahiyat Fakültesi Dergisi, Özel Sayı (1999): 2.
} 
yapan Onat'a göre temel sorun, programların ne kadar nitelikli olduğundan daha çok programı okutacak öğretim üyelerinin niteliği ile ilgilidir. ${ }^{25}$

İlahiyat müfredat programının hazırlanmasında eksiklikler ve aksayan yönler dikkate alınarak bir çalışma yürütülmüştür. Vurgu seçmeli derslere yapıldığı için bazı derslerin saatlerinin azaltıldığı yönünde bir eleştiri yapılmıştır. Yukarıda ifade edildiği üzere 1997 y1lında oluşan bu programda temel bilgilenmeyi kazandıracak olan dersler kredi saatleri de belirtilerek zorunlu olarak yer almıştır. Teoripratik bütünlüğünü belirleyecek olan dersler de seçmeli statütüsünde kabul edilmiştir. Proje dersler olarak tasarlanan bu dersler, beşinci yarıyıldan itibaren kredi saati olarak programa konulmuştur. Seçmeli dersler ihtiyaca ve isteğe bağlı olarak açılabilmektedir. ${ }^{26}$ Zorunlu ve seçmeli derslerin saatleri ve kredilerini karş1laştıran Onat, sorunun seçmeli derslerin öneminin yeterince anlaşılmamasından kaynaklandığı görüşündedir.

1997-1998 y1lında yürürlüğe konmuş bu programa yöneltilen en önemli eleştirilerden birisi de Arapça hazırlık sınıfının kaldırılması ve Arapça öğretiminde başarıya ulaşılamamış olmasıydı. Onat'a göre bunun çözümü, dilin gerekliliği ve öneminin ayırımında olan öğrencilere, yurt içi ya da yurt dışı imkânlar sağlanarak başarılı olmalarını temin etmekti. Bu konuda yeterli adımlar atılmadığ için başarıya ulaşılamamıştır. Dilin bir araç olup, asıl olan, ilahiyat alanında bilimsel bilginin üretilmesidir. Dil olmadan bu sahada bilim üretmenin mümkün olmadığı bilinmektedir. Ama Arapça bilmek de alim olmak için yeterli değildir. ${ }^{27}$ Böylece Onat, sürekli gündeme getirdiği İlahiyat alanında temel kaynaklara yönelik Arapça ve güncel konulara yönelik de bir Bat1 dili öğrenilmesi gerektiğine ilişkin düşüncesini tekrarlayarak pekiştirmiş olmaktadır.

\footnotetext{
25 Onat, "İlahiyat Fakültesinde Program Tartışmaları Üzerine", 310; Ayrıca bk. İLKE İlim Kültür Eğitim Derneği, Türkiye'de Din Eğitiminin Dönüşümü (19972012) (İstanbul: İlke Yayınları, 2012), 20, 154-157; YÖK 11.07.1997 tarih ve 97.23.1660 Sayıli Karar.

26 Tosun, "Almanya'da ve Türkiye'de İlahiyat Eğitimi”, 209 vd.

27 Onat, "İlahiyat Fakültesinde Program Tartışmaları Üzerine", 312.
} 
Hasan Onat, konuyla ilgilenenlerin önüne yüksek din öğretimiyle ilgili cevaplandırılması ya da tercih edilmesi gereken İki seçenek koyar; kutsalla uğraşmanın bireysel tatmini mi? Dini bir bütün olarak anlamak mı? O, bu seçeneklerin ikincisinden yana tavır koyar. Tüm bilimler insan ürünüdür, beşeridir. Dolayısıyla kutsal olduklarından söz edilemez. Kuran'in Allah'tan geliyor olması onunla ilgilenmenin kutsal bir iş olduğu anlamına gelmez. Hiçbir ilim İslâm la özdeşleştirilemez. Bu açıdan bakıldığında zihinlerdeki bilim algısının değiştirilmesi ve programların öğrencinin bilgiye açık olmasını sağlayacak şekilde dizayn edilmesi gerekir. Bilgi üretme süreçlerini bilmek, kaynaklara inmek ve yeni bilgiler üretmek önemlidir. İnsanlığın kaderinde etkili olanlar, bilgi üretenler ve bu bilgi gücüne sahip olanlardır. ${ }^{28}$ Onat, bazı çalışmalarında da tartışmaya açtı̆̆ı ve sorunlu bir yaklaşım olarak değerlendirdiği, ilim-bilim ikilemine ${ }^{29}$ de değinir. Müslüman bilim geleneğinden söz eder. İlahiyatta yapılan mevcut bilimsel çalışmalar, ne İslâm bilim geleneğinin devamıdır, ne de Batı bilimine eklemlenebilir. Müslüman bilim geleneğini yeniden diriltmek mümkün değildir. Din halini alan gelenek bilimin ve aklın alanını daraltmıştır. Yapılabilecek tek iş, yeni bir İslâm bilim geleneği inşa etmektir. Yeni gelenek, geçmiş İslâm bilim geleneğine mahkum olamayacağı gibi Batı bilim geleneğine de mahkum olamaz. Bilim anlama, açıklama faaliyeti ve bunu sistemli yürütme çabasıdır. Dolayısıyla ilahiyatçı da İslâmla ilgili tarihin akışı içerisinde ortaya çıkan muazzam birikimi anlamaya ve açıklamaya çalışır. Yeni bilimsel arayışlar içinde ilahiyatın önemli bir misyonu olacaktır. Bu yüzden müfredatın, programların yenilenmesi hayati önem taşımaktadır. Bu iş eleştirel zihniyet göz ardı edilerek yapılamaz. Bilimsellikten uzaklaşarak bunu yapmak faydadan çok zarar getirecektir. ${ }^{30}$ Böylece Onat, ak1l, yöntem ve eleştirel düşünce gelişmeden üniversiteden ve bilimden söz edilemeyeceğini israrla savunmaktadır.

Hasan Onat'in İslâm Mezhepleri Tarihi alanında takip ettiği metot ve görüşleri, onun yeni bir bilim paradigması oluşturma yönündeki girişimlerinden bağımsız ele alınamaz. $\mathrm{O}$, bilim alanından hareketle

\footnotetext{
28 Onat, "İlahiyat Fakültesinde Program Tartışmaları Üzerine", 314.

29 Onat, "Tarihin Anlam ve Önemi", 64 vd.

30 Onat, "İlahiyat Fakültesinde Program Tartışmaları Üzerine”, 315 vd.
} 
İlahiyat bilimlerinin konumunu belirleyip, İlahiyat Fakültesi'ni, bulunduğu üniversite bünyesinde evrensel kalitede bilim üretmesi gereken bir bilim yuvası olarak değerlendirdi. Malûmâta mahkum olmayan, süreçleri bilen, satır aralarını iyi okuyan ve değişimi algılayabilen Müslüman âlim modeline ilgi duydu. Hasan Onat'in öğrencilerine ve kendisini takip edenlere biraktığı en önemli miras, yeni bir medeniyetin inşası çerçevesinde ilâhiyat alanında yeni bir bilim paradigmasını tartışmaya açıyor olmasıydı. ${ }^{31}$ Buna bağlı olarak program çalışmalarıyla ilgili ilahiyat alanının bilimselliği konusuna da dikkat çekti. Hazırlanış sürecinde Batı'daki Islamic Studies bölümleriyle de karşılaştırmalar yapıldığını söyledi. Bu durum İslâm’ Batı üzerinden anlamak şeklinde yorumlandı. Oysa yapılan Batı'daki terminoloji ile Batılı kaynakları okumayı ve anlamayı sağlamaktı. Batı'yı anlamak önemli ama kendimize özgü koşullarımız, düşüncelerimiz ve değerlerimizi gözardı edemeyiz. Kendi bilim geleneğimizin olması bir gereklilik. Bu gelenek içerisinde değerlerimizi, sistemimizi ve yapılanmamızı gerçekleştirmemiz gerekir. ${ }^{32}$ Aslında bu görüş Hasan Onat'in başka yazı ve makalelerinde işlenmiş ve üzerinde durulmuş önemli bir konudur. Bu noktada onun yeni bir bilim paradigmasina dair usûl belirleme ve geliştirme çabaları ve belli başlı görüşleri önemli görünmektedir. Onat, İslâm coğrafyasında üretilen bilginin ve oluşan birikimin Endülüs, Sicilya ve Anadolu kültür havzaları kanalıyla Batı'y1 etkilediği, bu yolla bilimsel düşüncenin ve bilimin gelişmesine katkı sağladığı görüşünü dile getirdi. Ancak zamanla özgün niteliğini kaybeden Batılı bilim anlayışını; çıkara dayalı, değerleri sömüren ve Tanrı'dan uzaklaştırıcı niteliği nedeniyle gelecek açısından umut verici görmez. Müslümanların kültür ve medeniyette yaşadıkları zirve dönemlerin, bilim anlayışı ve bilimsel gelenekle ilgili olduğunu söyledi. Günümüzde de başarının, bu şekilde gerçekleştirilebileceğine vurgu yaptı. Çünkü yaşanılan koşullar Müslümanlara yeni bir bilim anlayışı oluşturma gibi bir sorumluluk yüklemektedir. Bu yeni anlayışın köklerini, tarihsel süreçte oluşan Müslüman ilim geleneğinde bulmak mümkündür. Tarih bilinci ile sürekli kendini inşa

\footnotetext{
31 Onat, "Tarihin Anlam ve Önemi”, 23.

32 Onat, "İlahiyat Fakültesinde Program Tartışmaları Üzerine”, 313.
} 
eden bilimin, gelecek tasarımına imkân sağlayacağına, bilgi ve bilimin gücüne sahip olamayanların, hiçbir zaman özne olamayıp, nesne olmaya mahkum olduklarına dikkat çekti. ${ }^{33}$ Ona göre Batı uygarlığının mevcut insan anlayışı, ürettiği bilim ve teknoloji, insanı mutlu etmekten uzaktır ve insanlığın geleceğini tehdit etmeye başlamıştır. Bu sebeple insanlığın yeni bir metafizik görüşe ve yeni yüksek evrensel değerler sistemine ihtiyacı bulunmaktadır.

Onat'ın İlahiyat programlarının yenilenmesine dair sürekli çözüm arayışında olduğu ve önerilerde bulunduğu görülmektedir. Üniversite mantalitesine uygun olarak İlahiyat fakültelerinin müfredatının, bilimsel amaç ve ülke çıkarları açısından yenilenmesi gereklidir. Her fakülte, içinde bulunduğu bölgenin özelliklerine ve bilim adamı yeterliliklerine uygun olarak arayışlara girebilmelidir. Bunun için YÖK "İlahiyat Eğitimi Ortak Paydası" denilebilecek bir çerçeve belirleyebilir. Her fakülte buna bağlı olarak kendi özgürlük alanı içinde bilim üretebilecek kararlar alabilir ve uygulayabilir. Ancak her şeyin bilimsel zihniyetle, kayıt altında ve şeffaf olması gerekir. Herhangi bir ilahiyat fakültesinin bir dini grup tekelinde olmasına da asla göz yumulmamalıdır. ${ }^{34}$

Onat 1997-1998 yıllarında Ankara İlahiyat Fakültesi'nin hocaları olarak güzel bir müfredat hazırladıklarını söyler. Ama daha iyisini yapma zamanı geldiğini de söyler. Ona göre Ankara İlahiyat Fakültesi'nde o dönem oluşturulan program izleme komitesi işletilebilseydi belki o programlar kendini sürekli yenileyebilecekti. Komitenin görevi, görülen aksaklıklar çerçevesinde programın sürekli daha iyiye götürülmesini sağlamaktı. Ama izleme komitesi uzun süre işletilememiştir. ${ }^{35}$

Onat müstakil bir bilim dalı olan İslâm Mezhepler Tarihi'nin Kelam bilim dalıyla birleştirilmesi çabalarına da eleştiri getirmiştir. Mezhep çatışmasının İslâm dünyasını tehdit ettiği bir zaman diliminde, bu alanda araştırma yapacak, İslâm Ortak Paydası bilincini

\footnotetext{
33 Onat, "İlâhiyat Bilimlerinde (Ulûmu Dîniyye) Yöntem Sorunu”, 41-45.

34 Onat, "İlahiyat Fakültesinde Program Tartışmaları Üzerine", 318.

35 Onat, "İlahiyat Fakültesinde Program Tartışmaları Üzerine", 316 vd.
} 
geliştirecek bir dersin işlevsizleştirilmesi, yaşanan gerçekliklerle bağdaşmamaktadır. Ilmi faaliyetlerini müstakil olarak sürdüren Kelam ve İslâm Mezhepleri Tarihi derslerinin yerine "Kelam ve İslâm Mezhepleri" adıyla, konulan yeni dersin içerikleri ve nasıl okutulacağ konusunda hiç düşünülmediğini dile getirmiştir. Hem bir akademisyen hem de Ankara İlahiyat Fakültesi bünyesindeki İslâm Mezhepleri Tarihi Anabilim dalının başkanı olarak Kelam ve İslâm Mezhepleri Tarihinin iki farklı disiplin olduğunu ve ayrı dersler olarak öğrencilere verilmesi gerektiği görüşünü savunmuştur. Mezhep tartışmalarının bu denli İslâm coğrafyasını tehdit ettiği bir zaman diliminde, klasik dönem mezhepleriyle ve yaşayan mezheplerle ilgili bilimsel araştırmalar yapan bir disiplinin, Kelam ile birleştirilerek işlevsiz kılınmasını, hem ulusal hem de evrensel gerçekliklere aykırı bulduğunu, hem yazılarında hem de bilimsel platformlardaki tartışmalarda defalarca gündeme getirmiştir.

\subsection{Din Kültürü ve Ahlâk Bilgisi ders rogramlarının yap1landirılması}

Türkiye'deki ilköğretim ve orta öğretimde okutulan Din Kültürü ve Ahlâk Bilgisi programı, ilk kez 1982 Anayasası'nın 24.maddesinde belirtilen ilkeler uyarınca "Din Bilgisi" ve "Ahlâk" derslerinin birleştirilmesiyle yürürlüğe girmiştir. Daha önceki düzenlemede isteğe bağl1 bir şekilde seçmeli olarak okutulan bu dersin yeni düzenlemeyle statüsü değiştirilmiş ve zorunlu dersler kategorisine alınmıştır. Bu program, Talim Terbiye Kurulu Başkanlığı'nın 18 Şubat 1982 tarih ve 30 sayılı kararı ile kabul edilmiş, 29 Mart 1982 tarih ve Milli Eğitim Bakanlığı'nın 2109 sayılı Tebliğler Dergisi'nde de yayınlanmıştır. Sonraki yıllarda dersin temel ilkeleri geliştirilmek amacıyla tekrar düzenlenmiştir. Bunlardan ilki 30 Ekim 1986 tarih ve 2219 sayılı Tebliğler Dergisi'nde yayımlanmıştır. Birkaç yılın ardından programın tekrar olarak görülen bazı üniteleri çıkarılıp yeniden yapılandırılarak, $13 \mathrm{Ni-}$ san 1992 tarih ve 2356 sayılı Tebliğler Dergisi'nde yayımlandığı dikkat çekmektedir. ${ }^{36}$ Bugün Din Kültürü ve Ahlâk Bilgisi dersi ilkokul,

36 Milli Eğitim Bakanlığı (MEB), 29 Mart 1982 tarih ve 2109 sayılı Tebliğler Dergisi; MEB, 30 Ekim 1986 tarih ve 2219 sayılı Tebliğler Dergisi; MEB, 13 Nisan 1992 tarih ve 2356 sayılı Tebliğler Dergisi. 
ortaokul ve lise düzeyindeki resmi ve özel tüm okullarda zorunlu statüde okutulmaktadır.

Hasan Onat, Din Öğretimi Genel Müdürlüğünün organize ettiği ilk, orta ve liseler için Din Kültürü Ahlâk Bilgisi program geliştirme çalışmalarında yer almış ve önemli katkılar sunmuştur. Tevhid-i Tedrisât kanunu uyarınca din eğitimi ve öğretimi, devletin kontrolünde ve Milli Eğitim Bakanlığı'na bağlı okullarda yapılmasını gerektirmektedir. Onat'a göre din eğitimine yönelik olması gereken de budur. Türkiye'nin özel koşulları ve İslâm dininin bazı yapısal özellikleri, din eğitim ve öğretiminin devletin denetimi ve gözetimi altında, devletin resmi kurumlarında yapılmasını bir zorunluluk haline getirmiştir. Buna bağlı olarak Onat, 1992 Anayasası ile zorunlu ders statüsünde verilen Din Kültürü ve Ahlâk Bilgisi derslerinin içeriklerinin ve veriliş biçimlerinin yeniden gözden geçirilmesi gerektiğini savunmuştur. $\mathrm{O}$, din alanında nitelikli bir eğitimden yana tavır koymuştur. Bu doğrultuda Kur'ân merkezli bir din anlayışını oluşturacak eğitim-öğretim, mezhepler üstü bir anlayışla, bilimsel ve çağdaş bir yaklaşımla verilmelidir. ${ }^{37}$

Onat, dini bilgi sahasında doğru bilgi sahibi olabilmenin farklı yollar1 olduğundan hareketle en doğru olanın, bu alanda bilimsel bilginin kazanılması ve kazanılan bilginin uygun bir şekilde halka taşınmasını sağlamak olduğu düşüncesindedir. Din Kültürü ve Ahlâk Bilgisi derslerini önemli hale getiren en önde gelen sebep, bu konunun toplumsal boyutu olan bir nitelik arz etmesidir. Türkiye'deki mezhebi dağılımdan söz eden ve kabaca bir mezhep dağılımı veren Onat, ülkemizdeki din anlayışının sözlü kültüre dayandığı tespitinde bulunur. Şifahi kültürden bilgi temelli bir yönteme varılması gerektiğini söyler. Bu noktada Din Kültürü ve Ahlâk Bilgisi derslerinin önemi ve gerekliliği kendini gösterir. Bu derslerin müfredat programlarına bakıldığında mezheplerüstü ve cemaatlerüstü bir yaklaşımla, Müslüman olarak kendini ifade eden bireylere dinin ortak paydasını öğretmeyi amaçladığı görülür. Bu temel payda, İslâm'in evrensel nitelikli olduğu bilinen kök değerlerinden meydana gelir. Böylece insanlığın

\footnotetext{
37 Onat, Din Anlayışında Değişim Süreci, 141.
} 
gereksinim duyduğu bir arada yaşama kültürü oluşturur. Aynı zamanda bunun altyapısında bulunması gereken evrensel ahlâk ilkelerinin tesis edilmesini temin eder. ${ }^{38}$ Böylece bu derslerin, dini bilgi aktarımı, kültürel değerlerin sunumu ve toplumsal bütünleşmede üstlenmesi gereken rolü ortaya konmuş olmaktadır.

Hasan Onat, 28 Şubat sürecinin en tartışmalı konusu olan sekiz yıllık kesintisiz zorunlu temel eğitimle ilgili de önerilerde bulunmuştur. Ona göre 6., 7. ve 8. sinıflarda seçmeli olarak konulacak Kur'ân1 Kerim metnini okuma ve mealinden anlamaya yönelik dersler, ülkemizde çokça tartışılan Kur'ân Kursları sorununu kökünden çözebilir. Din Kültürü Ahlâk Bilgisi derslerinde yapılacak içerik ve saate ilişkin düzenlemeler, seçmeli olacak Kur'ân Okuma ve Anlama dersleriyle ve dini bilgi sağlayacak bazı seçmeli derslerle desteklenirse İmam Hatip Liseleri, kendiliğinden birer meslek lisesine dönüşmüş olur. Çünkü İslâm dinine ilişkin doğru bilgiye ulaşan insanlar, çokça yapılan dinin istismarına izin vermeyeceklerdir. Din alanındaki bilgi boşluğu, dindar insanı vatan ve devlet gibi birçok milli değere düşmanlık noktasına bile götürebilmektedir. Onat'a göre bu anlayışın ortaya çıkmasında dini bilmeyen, dinin toplum açısından anlam ve öneminin farkında olamayan aydınlarımızın sorumluluğu büyüktür. İslâm öğretisinin, Kur'ân temelli bir biçimde ve bilimsel yöntemlerle, okullarda devlet tarafından öğretilmesi gerekmektedir. Sağlıklı ve mutlu insan; Tanrı ile, toplumla ve kendisiyle barış içinde olmak durumundadır. Bu da din alanında sağlanacak iyi bir eğitimle mümkün olabilir. ${ }^{39}$

Uygulanmaya başlandığı günden bu yana DKAB (Din Kültürü ve Ahlâk Bilgisi) dersleri, ülkemizde tartışmalı bir mesele olmayı sürdürmektedir. Bazı eğitimciler bu dersin anne-babanın tercihine bağlı olarak seçmeli olmasını savunurken bazı eğitimciler de programların Sünni anlayışa uygun bir şekilde hazırlandığından yola çıkarak programın geliştirilmesi yönünde görüş ortaya koymaktadır. Dersin zo-

\footnotetext{
38 Hasan Onat, "Din Alanında Doğru Bilgi Sahibi Olmanın Gerekliliği ve Din Kültürü ve Ahlâk Bilgisi Dersleri”, Eğitime Bakış 1/4 (Ekim, Kasım, Aralık 2005): 15-20.

39 Onat, Din Anlayışında Değişim Süreci, 142 vd.
} 
runlu olması gerektiğine yönelik en önemli gerekçe, bu dersin bir kültür dersi olarak görülmesidir. ${ }^{40}$ Farklı din anlayışlarının tarihten gelen bir dini ve kültürel miras olduğunu göz önüne alacak olursak DKAB derslerine ilişkin beklentiler farklılaşmaktadır. Bu bağlamda Alevî-Bektâşî kesimin DKAB dersinin seçmeli/zorunlu olmasının yanı sıra programın içeriğine ilişkin de farklı taleplerinin ve beklentilerinin olduğu açıkça görünmektedir. Hasan Onat'ın bu konuda da önemli tespitlerde bulunduğu ve bazı öneriler sunduğu dikkat çekmektedir. O, Din Kültürü ve Ahlâk Bilgisi derslerinin, mezheplerüstü-cemaatlarüstü bir yaklaşımla verilmesi gerektiği kanaatındadır. Bu konuda da ortak İslâm paydasından hareket ederek kendisini Müslüman olarak tanımlayan insanımıza gerekli dini bilginin verilmesi gerektiğini söyler. ${ }^{41}$

Hasan Onat, DKAB derslerinin zorunlu oluşunun Laiklikle bağdaşmadığ şeklinde ileri sürülen tezlerin yanlışlığına da değinir. Çünkü dünyanın birçok ülkesinde devleti yönetenler, kendi vatandaşlarını din konusunda bilgilendirmeye yönelik bir çaba ortaya koymaktadır. Türkiye'de tartışılan husus, devlet yöneticilerinin isteği doğrultusunda bir İslâm anlayışının dayatılmasının öne sürülmesidir. Bu tür iddialar ve bunun üzerine inşa edilen tartışmalar bilimsel içerikten yoksundur. Din Kültürü ve Ahlâk Bilgisi derslerinde herhangi bir mezhebin ya da cemaatin görüşleri anlatılmaz. Bu derslerin müfredatı gereğince bilimsel kriterlere bağlı olarak İslâm'ın temel ortak paydası verilmeye çalışılır. $O$, aksini savunanların programı yeterince incelemedikleri görüşündedir. Bu müfredatta her birey kendi kök değerlerini kolayca bulabilir. Alevilik-Bektaşilik anlayışına uy-

40 Konuya dair görüşler hakkında bk. Hüseyin Yılmaz, "Alevîlik-Sünnîlik Açısından Din Kültürü ve Ahlâk Bilgisi Dersleri“, Cumhuriyet Üniversitesi İlahiyat Fakültesi Dergisi, 13/2 (2009): 189-209; Cemal Tosun, "Din Kültürü ve Ahlâk Bilgisi Derslerinde Alevîlik“, Türk Yurdu, 25/210 (Ankara, 2005): 37-41; Nevzat Gencer, "Alevi Öğrencilerin Din Kültürü ve Ahlâk Bilgisi Dersine Karşı Tutumları Üzerine Bir Değerlendirme", Hitit Üniversitesi İlahiyat Fakültesi Dergisi, 19/1 (2020): 85-118.

${ }^{41}$ Hasan Onat, "Alevilik-Bektaşilik, Din Kültürü Ahlâk Bilgisi Dersleri ve Diyanet”. Erissim 10 Mart 2021. http://www.hasanonat.net/index.php/96-alevilikbektasilik-din-kueltuerue-ahlak-bilgisi-dersleri-ve-diyanet. 
gun tarzda bir Din Kültürü ve Ahlâk Bilgisi dersinin verilmesi gerektiği yönündeki iddiaların da bilimsel temellerden yoksun olduğunu ${ }^{42}$ savunur. Zaten böyle bir teklif, Tevhid-i Tedrisât kanununa da aykırı düşecektir. Çünkü bu kanuna göre "bir milletin bireyleri ancak bir eğitim görebilir. İki türlü eğitim bir ülkede iki türlü insan yetiştirir. $\mathrm{Bu}$ ise, duygu ve düşünce birliği ile dayanışma amaçlarını tamamen yok eder". ${ }^{43}$ Bir tarikat olan Bektaşilik temelinde bir Din Kültürü ve Ahlâk Bilgisi derslerinin olmasını istemek, tekke ve zaviyelerin kapatılmasını sağlayan kanuna da uygun olmayacaktır. Türkiye'de say1ları yüzlerle ifade edilebilecek dini hareket faaliyet göstermektedir. Alevilik-Bektaşilik anlayışı yönünde bir din dersi verilmesi, kendini Sünni olarak tanımlayan geniş kitleye ve dahası tüm gruplara, kendi istedikleri doğrultuda bir din eğitimi verilmesi gibi bir sonucu beraberinde getirecektir. $\mathrm{Bu}$ da din eğitimi alanında kaosu doğurur. ${ }^{44}$

Onat bu konuda Alevilik-Bektaşilik doğrultusunda hazırlanan kitapları da değerlendirmektedir. Şakir Keçeli ve Aziz Yalçın başkanl1ğında bir ekip tarafından hazırlanan kitaptan ve Esat Korkmaz'ın hazırladığı Fransa Alevi Birlikleri Federasyonu'nca yayınlanan kitaptan örnekler verir. Din Kültürü Ahlâk Bilgisi derslerinde okutulması düşünülen bu kitapların bilimsel yöntemden ve bilimsel içerikten yoksun olduklarını tespit eder. Dahası bu kitaplarda ciddi bilgi hataları bulunduğunu söyler. ${ }^{45}$ Aleviliği başlı başına bir din ya da felsefi bir din olarak değerlendiren ve Müslümanlık içerisinde yer vermeyen kendini Alevi olarak tanımlayan aşırı yaklaşımları eleştirir. Bunlara karşı en iyi cevabın yine Alevilik bünyesinden çıktığına değinir. ${ }^{46}$ Ortak paydanın merkezi bir yerde durduğu DKAB programlarının insanları buluşturacak uzlaşı zemini için de önemli olduğuna vurgu

42 Onat, "Alevilik-Bektaşilik, Din Kültürü Ahlâk Bilgisi Dersleri ve Diyanet". Hasan Onat, "Din Alanında Doğru Bilgi Sahibi Olmanın Gerekliliği”, 15-20.

43 Onat, "Alevilik-Bektaşilik, Din Kültürü Ahlâk Bilgisi Dersleri ve Diyanet".

44 Onat, "Alevilik-Bektaşilik, Din Kültürü Ahlâk Bilgisi Dersleri ve Diyanet". Hasan Onat, "Alevilik-Bektaşilik, Din Kültürü Ahlâk Bilgisi Dersleri ve Diyanet" Türk Yurdu, 25/210, (Şubat 2005).

45 Onat, "Alevilik-Bektaşilik, Din Kültürü Ahlâk Bilgisi Dersleri ve Diyanet".

46 Onat, "Kimlik-Teoloji İlişkisi Bağlamında Alevilik-Bektaşilikle İlgili Kimlik Tartışmaları Üzerine", Alevilik-Bektaşilik Araştırmaları Dergisi [Prof. Dr. Irene Melikoff'un anisina], 1 (2009): 25-26. 
yapar. ${ }^{47}$ Alevilik açılımı adı altında yürütülen çalıştaylara da katılan Onat, Alevi kesimin din öğretimi konusunda gündeme getirdiği problemlere vakıf biri olarak bazı çözüm önerilerinde bulunmuştur.

Onat, Din Kültürü ve Ahlâk Bilgisi derslerinin zorunluluğunu tartışmak yerine, nasıl daha verimli hale geleceğini tartışmanın daha önemli olduğu görüşündedir. Vakit kaybetmeden Türkiye'nin "bağ1ş1klık sistemini“ güçlendirmesi gerektiğini söyler. Bu da din anlayışıla alakalı sorunların üstesinden gelerek ve sağlıklı bir uzlaşı kültürüyle mümkün olabilir. Burada yine 1srarla yeni bir uygarlığın kök hücrelerini taşıdığını düşündüğü İslâm ortak paydasının öneminden ve gerekliliğinden söz eder. Bu ortak paydayı keşfeden insanlar, farkl1lığ1 ve çeşitliliği zenginlik olarak görebilir ve değerlendirebilir. Böylece enerjilerini daha güvenli bir Türkiye ve yaşanabilir bir dünya kurmak için harcayabilir. ${ }^{48}$ Meseleye bilimsel bir yaklaşımla çözümler üreten Hasan Onat'in bu çabaları oldukça değerlidir ve müfredat programına önemli katkılar sunmuştur.

\section{3. İlahiyat müfredatına uygun kitap çalışmaları}

Hasan Onat, Ankara Üniversitesi İlahiyat Fakültesi'nde hem lisans hem de lisans üstü dersler verdi. İnteraktif ders işleme yöntemi ve eleştirel düşünceyi merkeze alması, bu dersleri çok verimli hale getirdi ve öğrencileri açısından çok yararlı oldu. Lisans düzeyinde İslâm Mezhepleri Tarihi, Çağdaş İslâm Akımları, Türkiye'de Dini Akımlar, Sosyal Bilimlere Giriş, Sosyal İlimler Metodolojisi, İslâm Bilimlerinde Yöntem, Sosyal Değişme ve Din derslerine girdi. Yüksek Lisans ve Doktora düzeyinde ise İslâm Mezhepleri Tarihine Giriş, Mezhepler Tarihi Metodolojisi-I, Mezhepler Tarihi Metodolojisi-II, Çağdaş İslâm Akımları-I, Çağdaş İslâm Akımları-II, Alevilik-I, Alevilik-II derslerini okuttu. Onat'in verdiği derslerin yanı sıra uzmanlık alanına yönelik yazdığı kitapları, güncel konulara ve yaşanan sorunlara ilişkin yazdığı kitap ve makaleleri de bulunmaktadır.

Hasan Onat'in Yüksek Din Öğretimi alanında editörlüğünü yaptığ1 kitaplar şunlardır : İslâm Düşünce Ekolleri Tarihi (ANKUZEM, 2006),

\footnotetext{
47 Onat, "Alevilik-Bektaşilik, Din Kültürü Ahlâk Bilgisi Dersleri ve Diyanet".

48 Onat, "Din Alanında Doğru Bilgi Sahibi Olmanın Gerekliliği”, 15-20.
} 
İslâm Mezhepleri Tarihi El Kitabı (Ankara, 2012) ve İslâm'a Yeni Yaklaşımlar (Anadolu Üniversitesi AÖF Yayınları, Eskişehir, 1999). Ayrıca editörlüğünü Halis Albayrak'ın yaptığı İslâm Bilimlerinde Yöntem (ANKUZEM, 2006), editörlüğü M. Zeki İşcan'ın yaptığı İslâm Mezhepleri Tarihi (Erzurum Atatürk Üniversitesi AÖF yayınları, 2016) ve editörlügünü Adem Solak'ın yaptığı Güvenli Okullar (İstanbul, 2007) bölüm yazdığı kitaplar olarak sayılabilir.

İslâm Düşünce Ekolleri Tarihi, bütünleşik bir uzaktan eğitim modeline dayanan İlahiyat Lisans Tamamlama Programı (ILITAM) için yazılmış bir kitaptır. Onat'ın editörlüğünü yaptığı ve farklı alanlarda akademisyenlerin katkı sağladığı eserin amac1, Müslümanların ondört asırlık süreçte kültür ve uygarlık olarak ortaya koydukları düşünce ve bilimin arkaplanında yatan ana damarları ve temel zihniyeti göz önüne sermekti. Bu kitabın aynı zamanda, disiplinler arası işbirliğini gerçekleştirilebilen örnek bir yanı vardı. İslâm Mezhepleri Tarihi, Çağdaş İslâm Akımları ve Tasavvuf Tarihi; İslâm Düşünce Ekolleri adı altında, yeni bir bakış açısı ve yeni bir anlayışla hazırlandı ve hedef kitlesinin karşısına çıktı. Müslümanlık düşünce geleneğinin birikiminin, parçaları gözden uzak tutmaksızın bütüncül yaklaşımla anlaşılmasına zemin hazırladı ve bu gelenekte yer alan ilmi düşüncenin tecrübesinden yararlanma imkânı sağladı. İslâm Düşünce Ekolleri, İslâm Mezhepleri Tarihi'nin üzerinde durduğu Haricilik, Şia, Mu'tezile ve Mürcie gibi mezheplerin yanında, Ameli/F1khi mezheplerin düşünsel arka planlarını ortaya koymaya çalıştı. Kitabın açtığı pencerelerden biri de Tasavvufi birikimin keşfi ve eleştirel bir yaklaşımda değerlendirilmesiydi. Ayrıca İslâm Düşünce Ekolleri Tarihi, İslâm dünyasındaki yenileşme arayışlarına da yer verdi. 49

Hasan Onat'ın Sönmez Kutlu ile birlikte editörlüğünü yaptığ1 İslâm Mezhepleri Tarihi El Kitabı, Ankara başta olmak üzere birçok İlahiyat Fakültesi'nde okutulan İslâm Mezhepleri Tarihi ve Ankara Üniversitesi Açık ve Uzaktan Eğitim Fakültesi İlahiyat Lisans Tamamlama programında yer alan Yaşayan İslâm Mezhepleri ders müfredatına uygun olarak hazırlanmıştır. Onat'la birlikte 9 öğretim üyesi

49 Hasan Onat, İslam Düşünce Ekolleri Tarihi (Ankara: Ankuzem yayınları, 2009), XIX vd. 
tarafından hazırlanan kitap alanıyla ilgili önemli bir boşluğu doldurmaktadır. Günümüzde Müslümanların karşı karşıya olduğu en temel sorunlardan birisi, din temelli guruplaşmalar ve hizipleşmeler olan mezheplere ilişkin güvenli ve açık bilgiler sunmaktadır. Kur'ân'da yer alan "hepiniz birden Allah'ın ipine simsıkı sarılın, ayrılmayın." 50 ayeti ve $\mathrm{Hz}$. Muhammed'in mü'minlerin kardeş oldukları yönündeki ifadelerine rağmen Müslümanlar, kendi içlerinde din anlayışları sebebiyle gittikçe küçülen gruplara bölünmüşlerdir. Onat, sıkça üzerinde durduğu "Dinlerini paramparça eden, her grubun kendi sahip olduğu ile övündüğü kimseler gibi olmayın." 51 ayetini bu kitapta da zikretmiştir. Bu doğrultuda o, din ve mezhebin, farklılığını ve mezheplerin beşeri nitelikli oluşumlar olduğunu hatırlatır. Bu sebeple hiçbir mezhebin, kendisini İslâm'ın tek doğru anlama biçimi olarak iddia edemeyeceğini ve din ile aynileştirilmemesi gerektiğini ${ }^{52}$ israrla anlatır.

$\mathrm{Bu}$ eserin Giriş bölümünde İslâm Mezhepleri Tarihinin konusu, amacı ve yöntemi hakkında bilgi verilmektedir. Klasik dönem mezhepler tarihi yazıcılığının nitelikleri ve günümüz mezhepler tarihinin yöntemi karşılaştırmalı olarak anlatılmaktadır. Bu bağlamda bilgi toplama, tasnif yapma ve bilgi ve belgelerin fikir, olay, zaman ve mekan ile irtibatının kurulması; bilgi ve belgelerin etkin kullanılması; yeniden inşa ve değerlendirme aşamaları irdelenmektedir. Ayrıca bu bölümde din ve mezhep ilişkisi, İslâm ortak paydası ve alanın terminolojisi üzerinde durulmaktadır. ${ }^{53}$ Farklı yazarların yazdığı diğer bölümlerde ise Haricilik, Mürcie, Mu'tezile, İmamiyye Şiası, Zeydiyye, İsmaililik, Dürzilik, Nusayrilik, Ehl-i Sünnet, F1khi mezhepler, Maturidilik, Eş'arilik, Yezidilik, Vehhabilik, Babilik-Bahailik, KadıyanilikAhmedilik, Alevilik konuları ${ }^{54}$ isslenmektedir.

Hasan Onat, Halis Albayrak'in editörü olduğu İslâm Bilimlerinde Yöntem adlı kitapta "Bilgi, Bilim ve Yöntem" başlıklı bölümü yazmıştır. Kitabın bu kısmında bilimsel bilginin nitelikleri, İlahiyat çalışma-

\footnotetext{
50 Âl-i İmrân 3/ 103.

${ }^{51}$ Rûm 30/32.

52 Onat-Kutlu, İslam Mezhepleri Tarihi El Kitabı, 13 vd.

53 Onat-Kutlu, İslam Mezhepleri Tarihi El Kitabı, 19-58.

54 Onat-Kutlu, İslam Mezhepleri Tarihi El Kitabı, 63-606.
} 
larının bilimselliği, dinsel bilgi havuzu, vahyi bilgi-beşeri bilgi, kaynak, aidiyet ve içerik açısından bilginin sağlamlığı, kavramların güvenilirliği, fikir hadise irtibatı, zaman-mekan ve fikir kaymaları gibi konuları irdelemiştir. ${ }^{55}$ Onat'in bu konuları daha sonra kitap ve makale düzeyinde yeniden ele aldığı ve yeni kavramsallaştırmalarla geliştirdiği bilinmektedir.

Hasan Onat'in İlahiyat Önlisans Programı (İÖP) kapsamında hazırlanan kitaplara da katkı sağladığı anlassılmaktadır. Bu bağlamda İlahim Güler tarafından yazılan Dine Yeni Yaklaşımlar adlı kitabın da editörlüğünü yapmıştır. Kitap içeriğinde; Din, İslâm, Kur'ân'a yeni yaklaşımlar, Hz. Muhammed ve Sünnet'ine yeni yaklaşımlar, din ve tecdid, din ve hukuk, din ve siyaset, din ve bilim, kader meselesi, toplumsal değişme ve din, din ve tasavvuf gibi konu başlıkları yer almaktadır. ${ }^{56}$ Onat'in, Açık Öğretim kapsamında televizyon ve radyo programlarının yapımında ve yayınlanmasında da görev aldığı bilinmektedir.

\section{4. İlköğretim, Lise ve İmam-Hatip Lisesi Ders kitaplarına yönelik çalışmalar}

Hasan Onat, yüksek din öğretimine yönelik yazdığı kitapların yanı sıra öğrencileriyle birlikte ilköğretim ve lise müfredat programına uygun Din Kültürü ve Ahlâk Bilgisi ders kitapları yazdı. Ama süreçte ortaya çıkan bazı sebeplere bağlı olarak bu kitapların yayınlanması ve okutulması mümkün olmad1. Ancak Onat'n İmam-Hatip Liseleri müfredatına uygun hazırladığı ve bu okullarda okutulmuş olan ders kitapları vardır. Bu bağlamda Ahmet Akbulut'la birlikte hazırladığ1 Ders Geçme ve Kredi Yönetmeliğini Uygulayan İmam-Hatip Liseleri İçin Kelâm Ders Kitabı, Osman Aydınlı ve M. Mahfuz Söylemez ile birlikte hazırladığ Temel Dini Bilgiler, Osman Aydınlı ve Hilmi Demir ile birlikte hazırladığı Kelâm kitapları zikredilebilir. Hasan Onat'ın bölüm yazarı olarak görev aldığı kitap projeleri de oldu.

55 Hasan Onat, "Bilgi, Bilim ve Yöntem", İslam Bilimlerinde Yöntem, ed. Halis Albayrak (Ankara: Ankuzem yayınları, 2005), 1-22.

56 İlhami Güler, Dine Yeni Yaklaşımlar (Eskişehir: Anadolu Üniversitesi Yayınları, 1999), 1-158. 
İmam Hatip Liselerinde Hazırlık sınıfında okutulan Temel Dinî Bilgiler dersinin özel amaçlar1 ${ }^{57}$ dikkatle incelendiğinde öğrencinin özgür bir birey olarak yetişmesi yönünde bir çaba ortaya konduğu açıkça görülür. Bu bağlamda amaçlar arasında yer alan İslâm dininin her zaman ve mekânda yeniden anlaş1labilecek dinamik bir din olduğu vurgusu oldukça önemlidir. Onat'ın sürekli "geleneğin din olmadığı" üzerinde durması da bu dersin özgürleştirici ve eleştirel boyutuna ayrı bir önem verdiğini gösterir. Bu sebeple amaçlar arasında, İslâmın düşünce geleneğini/ geçmişi eleştirel bir yaklaşımla doğru anlayan ve geçmişin mirasından geleceği belirleme anlamında yararlanan bireyler yetiştirme yer almaktadır. ${ }^{58} \mathrm{Bu}$ özel amaçlar Onat'ın İslâm Mezhepleri Tarihi ile ilgili ortaya koyduğu yöntem arayışlarıyla paralellik arz eder. Amaçlar belirlenirken ve ünitelerin çerçevesi ortaya konurken dersin öğretmenine de bir alan bırakılmış ve öğrencinin yetiştirilmesine yönelik özel çabalar istenmiştir. Temel Dini Bilgiler dersinin ünite başlıkları arsında Din-Bilim İlişkisi, İslâm ve Ahlâk, Temel İslâm Bilimleri, Din ve Sosyal Değişme gibi önemli konular yer almaktadır. ${ }^{59}$ Temel Dini Bilgiler dersinin genel ve özel amaçları incelendiğinde hedef kitle olarak seçilen İmam-Hatip Liselerinde okuyan öğrencilerin, özgür, eleştirel bir kimliğe sahip olmalarının ve günümüz koşullarına uygun bir din anlayışıyla yetiştirilmelerinin hedeflendiği anlaşılmaktadır.

Hasan Onat'ın Ahmet Akbulut'la birlikte hazırladığı Ders Geçme ve Kredi Yönetmeliğini Uygulayan İmam-Hatip Liseleri İçin Kelâm Ders Kitabı adlı ders kitabı, bu yöndeki ilk deneyim çabası olarak önemlidir. İşlenen konu başlıkları arasında siyâsî ve itikâdî mezheplerin doğuşunda etkili olan sebepler, inanç mezheplerinin tasnifi, Ehl-i Sünnet ve diğer mezhepler arasındaki meseleler, iman esasları, iman ile

57 Temel Dini Bilgiler dersinin özel amaçları, genel amaçları ve içeriği hakkında bk. İmam-Hatip Lisesi-Anadolu İmam-Hatip Lisesi-Yabancı Dil Ağırlıklı İmamHatip Lisesi Meslek Dersleri Öğretim Programları (Ankara: Milli Eğitim Basımevi, 1999), 79-85.

58 IHHL Meslek Dersleri Öğretim Programları (Ankara: Milli Eğitim Basımevi, 1999), 80.

59 Hasan Onat-Osman Aydınl1-M. Mahfuz Söylemez, Temel Dini Bilgiler (Ankara: Milli Eğitim Basımevi, 2003), 9-112. 
küfür arasındaki sınır ve tekfirin tehlikeleri başlıkları öne çıkmaktadır. Yaşayan mezheplerin ve günümüz Müslümanlarının karşılaştığ en önemli sorunlardan biri olan tekfir üzerinde durulmakta ve tekfir mekanizmasının işletilmesinin Müslümanların birlik beraberliğini ve toplumun huzurunu bozduğu anlatılmaktadır. Tekfirin sebepleri olarak cehâlet, kıskançlık, menfaatler ve siyasi çıkarların geldiği ifade edilmektedir. Müslümanın amacının, diğer Müslümanları İslâm dairesi dışına çıkartmak olmadığı ve görünüşe bakarak tekfir etmenin Kur'ân'a uygun bir yaklaşım olmaktan uzak olduğu üzerinde durulmaktadır. 60

İmam-Hatip Liseleri XI. sınıfta verilen Kelâm dersinin amaçlarının belirlenmesi ve müfredat programının ${ }^{61}$ hazırlanmasında da Hasan Onat'ın önemli ölçüde katkısı olduğu anlaşılmaktadır. Dinin, insan için olduğu ve insanı 'iyi insan' yapmayı amaçlayan bir araç olduğu vurgusu oldukça önemlidir. Dinin evrenselliği, ilkelerinin mevcut koşullara göre yorumlanabilmesi ile doğrudan ilişkilidir. Yorumlarla güncele dokunamayan din, sorun çözemediği gibi kendisi bizzat sorun haline gelebilir. Bu noktada yorum becerisinin oldukça önemli olduğu görünmektedir. Değişim, yaşanan sürecin olmazsa olmazlarından bir olgu olarak karşımızdadır. Bunun ise öncelikli olarak insanların zihinlerinde gerçekleşmesi gereklidir. Düşünmenin eyleme yön veren ve onun bilinçli yapılmasını sağlayan bir aşama olduğundan da söz edilir. Kelam dersinin genel amaçları içinde inanç alanındaki farklılaşmaların nedenlerini kavrama; dini, dinamik bir süreç olarak yorumlama yeteneği kazanma; din görevlisinde olması gereken değerler sistemine uygun davranma alışkanlığ kazanma gibi nitelikler yer almaktadır. Bu dersin özel amaçları içinde de inanç alanında farklı mezheplerin ortaya çıkışını yorumlama; itikâdî mezhepler ve temel öğretilerinin açıklanması gibi hususlar yer almaktadır. ${ }^{62}$ Müfredat programı incelendiğinde Kelâm dersinin ünitelerinin şu şe-

60 Hasan Onat-Ahmet Akbulut, Ders Geçme ve Kredi Yönetmeliğini Uygulayan İmam-Hatip Liseleri İçin Kelâm (Ankara: Sek Yay., 1994), 10-110.

61 Kelam dersinin özel amaçları, genel amaçları ve içeriği hakkında bk. İmamHatip Lisesi-Anadolu Imam-Hatip Lisesi-Anadolu Imam-Hatip Lisesi-Yabanct Dil Ağırlıklı İmam-Hatip Lisesi Meslek Dersleri Öğretim Programları, 145-151.

62 İHL Meslek Dersleri Ögretim Programları, 145 vd. 
kilde belirlendiği anlaşılmaktadır; Kelam Bilimine Giriş, İtikâdî Mezhepler, Varlık ve Bilgi Sorunu, İman ve İnkar, Allah'ın Varlığı ve Birliğine İman, Meleklere İman, Kitaplara İman, Peygamberlere İman, Kaza ve Kadere İman, Ahirete İman, Din ve Vicdan özgürlüğü. 63 Kelâm dersinin genel ve özel amaçları incelendiğinde İmam-Hatip Liselerinde okuyan öğrenci profilinin günümüz koşullarına uygun bir din anlayışıyla ve donanımlı bir şekilde yetiştirilmelerinin hedeflendiği dikkat çekmektedir.

Hasan Onat bu kitaplarında mezhepler üstü tutuma işaret eder ve bu konunun önemine belirgin bir şekilde vurgu yapar. Mezhepler tarihçisinin, araştırmalarında mümkün olduğunca, mensup olduğu mezhebin görüşleri ve eğilimlerinden bağımsız bir şekilde mezhepler üstü olmaya veya mezheplere eşit mesafede durmaya gayret etmesi gerektiğini savunur. Dahası bu tutumun dini doğru anlamak için gerekli bir koşul olması sebebiyle toplumun katmanlarında yaygınlaşması gerektiğini düşünür. Bu çerçevede Onat, insanların, devletlerin ve toplumların birbirlerini anlamalarının doğru bilgilenme ile olacağına işaret eder. Bu da olaylara tarafsız bir şekilde bakmayla mümkün olabilir. Bu sebeple sadece araştırmacıların değil Müslümanların da mezhepler üstü düşünmeleri gerekir. İslâm'ın anlaşılma biçimleri olan mezheplerin İslâm'la özdeşleştirilmesi, İslâm'in belli bir grubun tekeline girmesi demektir. ${ }^{64}$ Böylesi bir durum, din hakkında doğru ve sağlıklı bilgilenmenin önündeki en büyük engeldir. Oysa mezhepler üstü tavır, hem dinin doğru bir şekilde anlaşılması hem de Türkiye'de yer alan farklı unsurların bir arada birlik ve beraberlik duygusu içerisinde yaşamasının güvencesidir. Mezhepler üstü yaklaşım, her mezhebin sonradan ortaya çıkmış beşeri oluşumlar olduğunu ve İslâmla özdeşleşemeyeceğini ortaya koyar. Bu yöntem, Kur'ân'in öğretisini ve Müslümanlığın yüksek değerlerini merkeze alan bir yap1lanmayı öngörerek erken devir idealizasyonunu, geçmişi kutsallaştırmayı ve geleneği dinleştirmeyi reddeder.

Türkiye'de orta dereceli okullarda okutulan Din Kültürü ve Ahlâk Bilgisi (DKAB) ders kitaplarında itikadî mezheplerin, İslâm düşünce

63 Hasan Onat-Osman Aydınl1-Hilmi Demir, Kelam (Ankara: Milli Eğitim Basımevi, 2006), 9-134.

64 Onat, Din Anlayışında Değişim Süreci, 16. 
geleneğinde düşünce ve ifade özgürlüğü ve farkl1lıkların bir arada yaşaması bağlamında bir sunumla verildiği dikkat çeker.

\section{SONUÇ}

Hasan Onat hocanın, uzmanlık alanına yönelik akademik çalışmalarının yanı sıra eğitim-öğretimin farklı alanlarında projeleri, faaliyetleri ve deneyimleri oldu. Hem din hem de bilime ilişkin yaptığ yetkin ve özgün değerlendirmelerde insanın merkezi konumuna işaret etti. Din öğretiminin program yapılandırma, uygulama ve bilgilendirme aşamalarında, Türkiye'deki mevcut din anlayışının ve Müslüman zihniyetinin arkasında yatan problemleri tespite çalıştı, analizlerde bulundu ve çözüm önerileri sundu.

Hasan Onat, Türkiye'nin ve İslâm dünyasının somut bir ilahiyat eğitimi meselesinin olduğunu hem yazılarında hem de ilmi platformlarda sürekli gündeme getirdi. Bu yönde eleştirel bakış açısıyla sorunun çözümüne yönelik araştırma ve incelemeye dayalı problem çözme stratejileri ve yöntemler geliştirme gereğine vurgu yaptı. O, İlahiyat fakültelerinin, ürettikleri din alanındaki bilimsel bilgiyle önemli bir işlev gördükleri düşüncesindeydi. Ancak İlahiyat fakültelerinin bilgi üretme konusunda ve entelektüel çabasında bazı sorunların bulunduğunu görmüş ve üzerinde tahliller yapmıştı. İlahiyat çalışmalarının bilimselliği konusunda birçok sorunu gündeme getirdi ve çözüm önerileri sundu. Onat, uzmanlık alanı İslâm Mezhepleri Tarihi alanına yönelik olarak bir metodoloji geliştirmeye talip oldu ve hinterlandı geniş bir etki oluşturabildi. Onun üzerinde durduğu zihniyet çözümlemesi, fikir-hadise irtibatı, kaynak kritiği ve süreç izleme yöntemleri, geliştirdiği metodolojiye değer katmakta ve özgün kılmaktadir.

Din öğretiminin her alanı Hasan Onat'ın gündeminde yer aldı, bu konulara akademik çalışmalarında yer verdi ve program komisyonlarında aktif bir rol oynadı. 1982 yılında İslâm Enstitülerinin İlahiyat Fakültelerine dönüştürülmesi ile Din Kültürü ve Ahlâk Bilgisi derslerinin zorunlu kategorideki programa yerleştirilmesi, Türkiye'de sosyal ve dini değişim açısından bir dönüm noktası olmuştu. Buna ilaveten 2000`li yıllara yaklaşıldığında hem İlahiyat programlarındaki 
yeniden yapılanma hem de 8 yıllık temel eğitim kararı kritik dönemeçlerdi. Bu süreçlerde Hasan Onat isminin hem yazdıklarıyla hem de aldığ1 görevlerle etkin bir rol üstlendiği görülmektedir. Program yenileme çalışmalarında düşünce ekollerinin, mezheplerin ve dini eğilimlerin, köklere ve zamanın koşullarına bağlı gelişmelerini açıklamaya özen gösterirdi. İslâm mezheplerinin birbiriyle irtibatını ve bağlantılar/ilişkiler ağını doğru okuma yönünde önerilerde bulundu. $\mathrm{Bu}$ alandaki tecrübelerini Din Öğretimine yönelik program çalışmalarında ve ders kitabı yazım süreçlerinde başarılı bir şekilde uygulama imkânına sahip oldu. O, din öğretiminde Kur'ân'1 referans alan, tarih ve kültürel miras bilincine sahip olan, dini sahada temel bilgi ve yöntemin gereğini fark eden, güncel meselelere ilgi gösterebilen bireyler yetiştirme hedefini hep canlı tutmaya çalıştı.

\section{Kaynakça}

Aydın, Muhammed Şevki. Cumhuriyet Döneminde Din Eğitimi Öğretmeni Yetiştirme ve İstihdamı. İstanbul: Dem Yayınları, 2005.

Aydınlı, Osman. Osmanlı'dan Cumhuriyet'e İslâm Mezhepleri Tarihi Yazıcılığı. Ankara: HititKitap Yayınları, 2008.

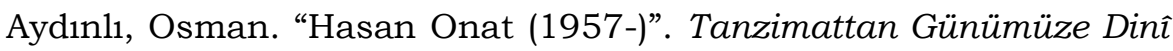
ve Tasavvufì Düşünce Temsilcileri. Ed. Süleyman Hayri Bolay. 6:4234-4246. Ankara: Nobel Yayınlar1, 2015.

Ayhan, Halis. Türkiye'de Din Eğitimi (1920-1998). İstanbul: M.Ü. İlahiyat Fakültesi Vakfı Yayınları, 1999.

Ayhan, Halis. "İlahiyat Fakültesi". Din Eğitimi Araştırmaları Dergisi 6 (1999): 255-268.

Gencer, Nevzat. "Alevi Öğrencilerin Din Kültürü ve Ahlâk Bilgisi Dersine Karş1 Tutumları Üzerine Bir Değerlendirme". Hitit Üniversitesi İahiyat Fakültesi Dergisi 19/1 (2020): 85-118.

Güler, İlhami. Dine Yeni Yaklaşımlar. Eskişehir: Anadolu Üniversitesi Yayınları, 1999.

İLKE İlim Kültür Eğitim Derneği. Türkiye'de Din Eğitiminin Dönüşümü (1997-2012). İstanbul: İlke Yayınları, 2012.

İmam-Hatip Lisesi-Anadolu İmam Hatip Lisesi-Yabancı Dil Ağırlıklı İmam-Hatip Lisesi Meslek Dersleri Öğretim Programları. Ankara: Milli Eğitim Basımevi, 1999. 
Milli Eğitim Bakanlı̆̆ Tebliğler Dergisi. 63/2517. Ekim 2000.

Onat, Hasan. Türkiye'de Din Anlayışında Değişim Süreci. İstanbul: Endülüs Yayınları, 2016.

Onat, Hasan. İslâm Ortak Paydası ve Mezhep Gerçeği. İstanbul: Endülüs Yayınları, 2019.

Onat, Hasan. "Bilgi, Bilim ve Yöntem". İslâm Bilimlerinde Yöntem. Ed. Halis Albayrak. Ankara: Ankara Üniversitesi Uzaktan Eğitim Yayınları, 2005.

Onat, Hasan. "Bilim, Bilimsel Yöntem ve İslâm/İlâhiyat Bilimlerinde (Ulûmu Dîniyye) Yöntem Sorunu". Modern Dönemde Dinî Illimlerin Temel Meseleleri İmî Toplantı. İstanbul: İSAM Yayınları, 2007.

Onat, Hasan. "İslâm Bilimleri ve Yöntemi Açısından Tarihin Anlam ve Önemi”. Kur'an ve İslâmi İlimlerin Anlaşılmasında Tarihin Önemi. Ed. M. Mahfuz Söylemez. Ankara: Ankara Okulu Yayınlar1, 2013.

Onat, Hasan. İslâm Düşünce Ekolleri Tarihi. Ankara: Ankuzem yayınlar1, 2009.

Onat, Hasan. "İlahiyat Fakültesinde Program Tartışmaları Üzerine". Türkiye'de Illahiyat Fakültelerinin Konumu ve Dini Bilginin Niteliği. Ed. Mahmut Ay-Rabiye Çetin. Ankara: A.Ü. İlahiyat Fakültesi Yayınlar1, 2016.

Onat, Hasan. "Din Alanında Doğru Bilgi Sahibi Olmanın Gerekliliği ve Din Kültürü ve Ahlâk Bilgisi Dersleri”. Eğitime Bakış. 1/4 (Ekim, Kasım, Aralık 2005): 15-20.

Onat, Hasan."Alevilik-Bektaşilik, Din Kültürü Ahlâk Bilgisi Dersleri ve Diyanet". Türk Yurdu, 25/210 (Şubat 2005): 8-13.

Onat, Hasan. "Alevilik-Bektaşilik, Din Kültürü Ahlâk Bilgisi Dersleri ve Diyanet". Erişim 10 Mart 2021. http://www.hasanonat.net/index.php/96-alevilik-bektasilik-din-kueltuerue-ahlak-bilgisi-dersleri-ve-diyanet.

Onat, Hasan. "Kimlik-Teoloji İlişkisi Bağlamında Alevilik-Bektaşilikle İlgili Kimlik Tartışmaları Üzerine". Alevilik-Bektaşilik Araştırmaları Dergisi [Prof. Dr. Irene Melikoff'un anısına]. 1 (2009): 1834.

Onat, Hasan. "Dinî Bilgi Üretimi ve Toplumsal Karş1lı̆ı Bağlamında İlahiyat Fakültelerinin Konumu". Dinî Temsil Sorunu Sempozyumu -Tebliğler-. (28-29 Nisan 2017, 2018): 31-44. 
Onat, Hasan. "Niçin Din Eğitimi”. Uluslararası Din Eğitimi Sempozyumu Bildirileri. Ankara: AÜİF ve TÖMER Yayınları, 1997.

Onat, Hasan-Akbulut, Ahmet. Ders Geçme ve Kredi Yönetmeliğini Uygulayan İmam Hatip Liseleri İçin Kelâm. Ankara: Sek Yayınları, 1994.

Onat, Hasan-Kutlu, Sönmez. İslâm Mezhepleri Tarihi El Kitabı. Ankara: Grafiker Yayınları, 2012.

Onat, Hasan-Aydınlı, Osman-Söylemez-M. Mahfuz. Temel Dini Bilgiler. Ankara: Milli Eğitim Basımevi, 2003.

Onat, Hasan- Aydınlı, Osman-Demir, Hilmi. Imam-Hatip Liseleri Kelâm. Ankara: Milli Eğitim Basımevi, 2006.

Öcal, Mustafa. "İlahiyat Fakültelerinin Tarihçesi". Uludağ Üniversitesi Ilahiyat Fakültesi Dergisi. 1/ 1 (1986): 111-123.

Kutlu, Sönmez. "İslâm Mezhebleri Tarihinde Usûl Sorunu”. İslâmi Ilimlerde Metodoloji/Usul. Mes'elesi-I. 391-440. İstanbul: Ensar Yayınlar1, 2005.

Kutlu, Sönmez. "Gelenekçi-Zâhirî İslâm Anlayışının Zihniyet Analizi: Epistemolojik". Teolojik ve Kültürel Temelleri, Zâhirî ve Selefî Din Yorumu. 19-80. Ankara: Kuramer Yayınlar1, 2019.

Tosun, Cemal. "Din Kültürü ve Ahlâk Bilgisi Derslerinde Alevîlik". Türk Yurdu, 25/210 (2005): 37-41.

Tosun, Cemal. "Almanya'da ve Türkiye'de İlahiyat Eğitimi". Türkiye'de İlahiyat Fakültelerinin Konumu ve Dini Bilginin Niteliği. Ed. Mahmut Ay-Rabiye Çetin. Ankara: A.Ü. İlahiyat Fakültesi Yayınlar1, 2016.

Yazıcığlu, M. Sait. "Cumhuriyetin 75. Yılında Din Öğretiminde Yeni Hedefler". Ankara Üniversitesi İahiyat Fakültesi Dergisi. Özel Say1/1999: 1-8.

Yılmaz, Hüseyin. "Alevîlik- Sünnîlik Açısından Din Kültürü ve Ahlâk Bilgisi Dersleri". Cumhuriyet Üniversitesi Ilahiyat Fakültesi Dergisi. 13/2 (2009): 189-209.

YÖK. İahiyat Fakülteleri Öğretmen Yetiştirme ve Lisans Programlar. Ankara: YÖK Yayınları, 1998. 


\section{SUMMARY}

Hasan Onat was recognized as one of the distinguished the scholars who made valuable contributions to both contemporary Muslim thought and the discipline of History of Islamic Sects in terms of method and content. The Holy Quran had a central role in the world of thought of Onat, who gave importance to the reconstruction of Islamic sciences. Starting from the concept of revelation, he stated that the mind and nature are also Allah's verses, similar to the fact that the Qur'an is a verse of Allah. For this reason, he emphasized that reason, science and revelation are always complementary to each other. In this direction, he drew attention to the importance of understanding the holy book and making sense of life in this direction. According to Onat, it is the Qur'an that is decisive in the field of worship and morality as well as in the field of belief. These principles determined by Revelation, It is clearly demonstrated in his life by the examples of $\mathrm{Hz}$. Muhammad. For this reason, he took care to keep the founding principles, which he conceptualized as "the common denominator of Islam", on the agenda. His discourse in this direction attracted the attention of those interested in religious tradition and religious knowledge.

Onat advocated the necessity of a new understanding of religion and science in order to ferment a new civilization suitable for human nature for the future of humanity. In this context, he focused on the formulation of the root science paradigm. The method principles determined in this framework are of the nature to guide both the natural sciences and the humanities. All branches of science can have the opportunity to establish and apply their own methods on this common ground. Onat also tries to determine the place of theology sciences in the spectrum of sciences. These sciences take place in the field of human sciences and carry out their research as a sub-branch of it. They are at least as scientific as the natural sciences. In the faculties of theology, knowledge is obtained by using scientific methods and techniques in disciplines such as Tafsir, Fiqh, Hadith, History of Islam, Kalam, Sufism, and History of Islamic Sects.

The necessity of religious education in different processes of education and how it should be done continues to be on the agenda as a 
problem waiting to be solved. Hasan Onat mentioned that religion is a phenomenon that humanity cannot give up and cannot exclude. According to him, the knowledge emptiness emerging in the field of religion and values will pose a serious threat to the future of humanity. It is possible to fill this lack by raising religious intellectuals and designing deep-rooted education policies. In order for the universal aims of education to be realized, the support of religion is needed. It proposes to benefit from a correct understanding of religion in achieving the basic aims of education. Only a knowledge-based understanding of religion can realize the mental change that education aims at.

Onat sought an answer to the question of why people need religious education. According to him, the most valid way for a person to realize himself is to seek Allah's approval and love. It is clear that a human being, who is also a social being, cannot build himself by ignoring society. From this point of view, religion emerges as a tool that contributes significantly to the right thinking of the individual, raising awareness and realizing the best. In this regard, education cannot be said to be a source of motivation on its own. The main duties of the prophets sent throughout the history of humanity have been to warn people with the revelation they received from Allah and to show them the ways of thinking correctly. Education enables the individual's creative abilities to be discovered, developed and activated. Religion demands the use of creative abilities from people and the creation of culture and civilization that will enable them to reach human values. Education teaches people how this process can be accomplished in the most profitable and productive way.

It is known that program works are carried out in different periods in the area of Religious Education and Higher Religious Education in Turkey. It is noteworthy that Ankara University Faculty of Theology and its academic staff take an active role in the program studies in this field. Hasan Onat, who worked as an academician at this university, had original ideas about education and training, especially in the field of Theology. He brought up that Turkey and the Islamic world is a concrete theological education matters in his writings and on scientific platforms. In this direction, he emphasized the need to develop problem-solving strategies and methods based on research 
and analysis for the solution of the problem. He thought that the theology faculties had an important function with the scientific knowledge in the field of religion they produced. However, he saw that there were some problems in the intellectual effort of theology faculties and made analyzes on them. He brought up many problems about the scientificness of theology studies and offered solutions. Onat aspired to develop a methodology for his field of specialization, History of Islamic Sects, and its hinterland exerted a wide influence. The mentality analysis, idea-event connection, resource critique and process monitoring methods he focuses on add value to the methodology he developed and made it unique.

In the final analysis, it is seen that Hasan Onat takes an active role in different processes of education, both with his writings and the tasks he undertakes. He contributed by taking part in program improvement commissions at different levels of education and by writing textbooks. In the years following 1997, he took part in the renewal activities of Imam-Hatip High Schools and Primary Education Religious Culture and Morals curriculum. In the books he wrote on religious education in Turkey; He focused on freedom of thought, the value of human, the necessity of change and renewal in Islam. He took care to explain the development of schools of thought, sects and religious tendencies according to their roots and the conditions of the time. 